\title{
WestVirginiaUniversity
}

THE RESEARCH REPOSITORY @ WVU

Law Faculty Scholarship

WVU College of Law

2020

\section{Climate Change Disobedience}

Charles R. DiSalvo

West Virginia University College of Law, charles.disalvo@mail.wvu.edu

Follow this and additional works at: https://researchrepository.wvu.edu/law_faculty

Part of the Civil Law Commons, and the Environmental Law Commons

\section{Digital Commons Citation}

DiSalvo, Charles R., "Climate Change Disobedience" (2020). Law Faculty Scholarship. 43.

https://researchrepository.wvu.edu/law_faculty/43

This Article is brought to you for free and open access by the WVU College of Law at The Research Repository @ WVU. It has been accepted for inclusion in Law Faculty Scholarship by an authorized administrator of The Research Repository @ WVU. For more information, please contact beau.smith@mail.wvu.edu. 


\title{
CLIMATE CHANGE DISOBEDIENCE
}

\author{
Charles R. DiSalvo*
}

\begin{abstract}
Among those who recognize climate change as an existential threat, some are willing to take dramatic action against it by committing civil disobedience. Activists, such as those taking part in the Extinction Rebellion in the United Kingdom, are willing to exchange their liberty for some putative good.

There is no discussion in the disobedience literature of the discrete purposes of climate disobedience or the principles by which climate activists ought to be guided in seeking to fulfill those purposes. This Article takes on that task.

After offering an overview of the purposes of civil disobedience, this Article isolates those purposes relevant to a climate disobedience campaign, identifies those principles by which climate disobedients should abide to achieve the purposes most attainable by climate disobedience, analyzes a serious limitation inherent in climate disobedience, and suggests measures to counteract the effects of the limitation. Finally, it critically examines Extinction Rebellion with a view to more effective future disobedience.
\end{abstract}

INTRODUCTION

I. A PRIMER: THE PURPOSES TO WHICH CIVIL DisOBEDIENCE MAY BE PUT.

A. Honoring Conscience.

B. Testing the Law

C. Advancing the Debate

D. Creating Change

1. By Creating a Crisis

2. By Withdrawing Cooperation

3. By Simultaneous Multiple Methods....

II. PRINCIPLES OF EFFECTIVE CiVIL DisobedienCE Against Climate Change.

A. Creativity.

B. Specificity of Goal

C. Evocativeness and Media Engagement.

1. Women's Suffrage

* Woodrow A. Potesta Professor of Law, West Virginia University College of Law. The author thanks the Arthur B. Hodges Fund for its generous grant made in support of this Article. 
2. The Salt Campaign

3. The Freedom Rides

D. Campaign Integration

E. Timeliness of Action

III. OVERCOMING AN INHERENT DISADVANTAGE

IV. ExTINCTION REBELlion: A PRELIMINARY ANALysis

A. Disruption.

B. XR Successes

1. Did Extinction Rebellion Create Substantive

Change?

CONCLUSION

"The time for polite petitioning has passed. We have a collective responsibility to address the climate crisis and the right to resist the activities of governments and fossil fuel corporations that perpetuate it. In the courts of law, in the audience of public opinion, and in the tribunal of history, we will stand justified in our resistance to the fossil fuel system."1

\section{INTRODUCTION}

Over one hundred years ago, British women willingly went to jail for the cause of suffrage - and helped women win the vote.

Ninety years ago, Indian activists willingly went to jail for the cause of independence - and helped move India closer to freedom.

Fifty years ago, American protestors willingly went to jail for the cause of peace - and helped end the Vietnam War.

Today, citizens around the globe are willing to go to jail once more. Their cause? The preservation of what remains of a healthy environment and the prevention of catastrophic climate change. Like the problems that challenged previous generations to surrender their freedom, climate change, too, is a serious problem-but this problem threatens the wellbeing, and perhaps even the existence, of our species.

Despite coming face-to-face with increasingly-ominous danger signals, the world is failing to come to grips with climate change. ${ }^{2}$ In

1. Statement of Climate Civil Resistance, Climate Def. ProjeCt, https://climatedefense project.org/statement-of-climate-civil-resistance/ [https://perma.cc/M6T8-YLRM] (last visited Apr. 21, 2020).

2. See, e.g., Oliver Milman, Ex-NASA Scientist: 30 Years On, World Is Failing 'Miserably' to Address Climate Change, THE GuARDIAN (June 19, 2018, 1:00 AM), https://www.theguardian .com/environment/2018/jun/19/james-hansen-nasa-scientist-climate-change-warning [https:// perma.cc/Q2SA-GP8D] (quoting former NASA climate scientist James Hansen); Jeff Tollefson, 
response, climate activists, concerned with preventing the worst effects of climate change, feel compelled to take more and more serious measures - including civil disobedience. ${ }^{3}$

When climate activists commit civil disobedience, they are betting that they will receive something valuable in return for the surrender of the most precious currency civil disobedients have-their freedom. Activists owe it to themselves and their movement to do everything in their power to obtain the greatest possible return on their investment. Since it is obviously in very limited supply, freedom should not be traded without careful thought and planning. This Article is intended to be a help in that process. In it, I argue that a set of principles exists that drive effective civil disobedience that climate activists would be wise to recognize, understand, and follow. I also argue that there exists a limitation, inhering in climate disobedience, to which activists must adapt to be successful.

Part I lays out the possible purposes of civil disobedience and identifies the central achievable purposes of climate change disobedience. Part II introduces five principles for effective climate change civil disobedience. Part III discusses a peculiar difficulty associated with climate change disobedience and makes recommendations about how to deal with it. Part IV applies the principles to a current climate change movement, Extinction Rebellion, and offers an analysis of the effectiveness of the civil disobedience employed by the movement.

Can the World Kick Its Fossil-fuel Addiction Fast Enough?, NATURE (Apr. 25, 2018), https://www.nature.com/articles/d41586-018-04931-6 [https://perma.cc/3MVN-SDVP] ("[B]y and large, governments are falling well short of their commitments [to the Paris Climate Accord], both collectively and individually. Many countries are likely to miss the emissions targets that they made in 2015 , and the world is on track for more than $3{ }^{\circ} \mathrm{C}$ of warming by the end of the century ....).

3. As this Article is being written, large scale civil disobedience-under the banner "Extinction Rebellion"-is being staged in the United Kingdom and elsewhere. See Ceylan Yeginsu, Climate Protests in London Occupy Major Landmarks, N.Y. TIMES (Apr. 17, 2019), https://www.nytimes.com/2019/04/17/world/europe/climate-change-protests-london.html [https://perma.cc/7KMA-TVVJ]. For a discussion of Extinction Rebellion, see Part IV infra. 


\section{A Primer: The Purposes to Which Civil Disobedience CAN BE PUT}

Before we can address the question of what principles, if adhered to, might make climate change civil disobedience ${ }^{4}$ effective, we first must ask a preliminary question. What are the purposes of those who engage in civil disobedience? What goals do disobedients intend to achieve? ${ }^{5}$

\section{A. Honoring Conscience}

Over the thousands of years that civil disobedience has been practiced, a broad, but fairly clear, range of goals has emerged. One goal common to almost all acts of civil disobedience is honoring of the disobedient's conscience. ${ }^{6}$ By disobeying, disobedients cleanse their consciences, separating themselves from the wrongs they disdain. A clear example is the refusal to pay federal income taxes on the part of a taxpayer who is conscientiously opposed to war on religious or moral grounds. By refusing to pay taxes that might be used for the war effort, the disobedient taxpayer attempts to satisfy his or her conscience. The disobedient harbors no illusions that his or her resistance will affect the war-making course of the government. That is not the disobedient's concern. The disobedient's concern is in creating as clear a separation as possible between the government's actions and himself or herself so that the disobedient has no direct religious or moral culpability for war-making. ${ }^{7}$

4. It is an implicit assumption of this Article that the disobedience under discussion is to be nonviolent.

5. This is not an idle question. Too often activist groups thoughtlessly embark upon civil disobedience. Invitations from activist groups to "a day of action" against a particular governmental or corporate policy typically contain the day's schedule. It often goes like this:

9 am: lectures, film, discussion

Noon: lunch

$1 \mathrm{pm}$ : cd training

$2 \mathrm{pm}$ : march to office of [name of the opponent]

3 pm: cd

This is the worst possible approach to civil disobedience. It squanders its power. It cheapens it. It makes it unremarkable. Civil disobedience embarked upon with no specific goal in mind is likely to culminate in an ambiguous and unsatisfactory end while wasting valuable resources. Climate disobedients can better understand what methods they should use, impart a sense of direction to their cause, and advance the larger movement by establishing a clear idea of what they specifically intend to achieve by engaging in disobedience.

6. Acts of civil disobedience can-and frequently do-have multiple, overlapping purposes. See Kimberley Brownlee, Civil Disobedience, Stan. Encyclopedia Phila. (Dec. 20, 2013), https://plato.stanford.edu/entries/civil-disobedience/ [https://perma.cc/MQQ5-3782].

7. A form of this approach is found among some religiously-motivated disobedients who 
Similarly, a climate activist, thinking about the failure of society to harness carbon emissions and the activist's own responsibility for generating emissions in daily life, might attempt to soothe his or her conscience by an act of disobedience.

The difficulty that this disobedient faces is that there will rarely be a climate law for the disobedient to disobey. For reasons described in Part III, virtually all possible climate disobedience is indirect civil disobedience - the violation of a law with which one has no quarrel to protest a policy or law to which one does object.

Because almost all possible climate change disobedience is indirect civil disobedience, it will be the rare instance in which climate change disobedience is undertaken solely to honor conscience. In indirect civil disobedience, there is no direct, personal, religious, or moral culpability at issue. Accordingly, the disobedience is motivated by a desire to attack an evil for which the disobedient usually has no direct, individual, religious, or moral responsibility. This brings into play the purposes of disobedience (described below) that are not directly related to the honoring of conscience. The result is that in the climate change arena there will be very few, if any, acts undertaken solely to honor conscience. Rather, the disobedient will almost certainly be forced, willingly or unwillingly, to add another civil disobedience goal or goals to his or her goal of honoring conscience.

\section{B. Testing the Law}

A second possible goal of civil disobedience is to test the law. This was a commonly-used approach during the American civil rights movement. African-Americans violated laws holding segregation in place to create opportunities for the courts to rule those laws invalid. ${ }^{8}$ Testing the law rarely is possible in the climate change arena because, again, virtually all climate disobedience is indirect; there are no laws whose validity activists can test because usually there are no relevant laws for them to break. There are, for example, no laws an activist can break to test the validity of the absence of a carbon tax.

Neither of these two worthy goals - honoring conscience and testing the law-will be the focus of our attention here. The first-honoring conscience - is easy enough to implement; the usual consideration of the factors that make disobedience effective is not necessary. Faithfulness to conscience is the issue, not effectiveness. The second - testing the lawis almost always impossible to implement in the climate change context.

concern themselves not with effectiveness, but faithfulness. For a discussion of the relationship of faithfulness to effectiveness, see Tom Harder, The Dichotomy Between Faithfulness and Effectiveness in the Peace Theology of John Howard Yoder, 81 MennONite Q. REv. 227, 227 (2007).

8. See, e.g., Brown v. Louisiana, 383 U.S. 131, 133 (1966). 


\section{Advancing the Debate}

Unlike honoring conscience and testing the law, at least two other important potential goals have relevance for climate activists. These two goals can have, especially in the area of climate change, an interlocking relationship.

To advance the debate. What does it mean for civil disobedience to "advance the debate?" It can be understood as changing what we might call "the national conversation." The national conversation is defined by the issues that the key players on the national stage - the media, government officials, politicians, public intellectuals - are discussing and what they are saying about them. The national conversation is important because it sets up a framework for what is politically possible. If a proposal does not find some significant resonance in the national conversation - if it is not part of the national narrative - it stands very little chance of becoming recognized as a custom, policy, or law. It is simply not on the agenda. ${ }^{9}$

When women were barred from voting in federal elections, Susan B. Anthony was prosecuted for unlawfully voting in the 1872 presidential election. ${ }^{10}$ Forty-eight years later, in 1920, the country approved the Nineteenth Amendment to the Constitution, recognizing the right of women to vote. ${ }^{11}$ What changed? The national conversation was one key factor that changed. The persistent civil disobedience of women - and the suffering they endured-kept women's suffrage in the conversation. ${ }^{12}$ Women repeatedly and relentlessly picketed President Wilson in front of the White House. ${ }^{13}$ They were arrested and jailed under harsh conditions in the Occoquan workhouse in Virginia. ${ }^{14}$ They engaged in hunger strikes to protest their incarceration and their living conditions. ${ }^{15}$ The conversation the women helped create was all about their cause. They never gave up under the most difficult conditions. Because they controlled the national conversation, a narrative was built that put immense pressure on politicians. President Wilson, the Congress, and eventually the requisite number of states surrendered to the narrative. ${ }^{16}$ Women won recognition of their right to vote.

In 2019, it appears that it is difficult for some influential politicians as well as large swaths of the public to see the immediacy of the threat of

9. N.E.H. Hull, The Woman Who Dared to Vote (2012).

10. Id.

11. U.S. CONST. amend. XIX.

12. See Robert P. J. Cooney, JR., Winning the Vote: The Triumph of the American Woman SufFrage MOVEMENT 343 (2005).

13. Id.

14. Id. at 348-49, 355 .

15. Id. at 361 .

16. Id. 
climate change. Public opinion and politicians sometimes seem to react only to disasters. This might help to explain why a national conversation about the urgent need for immediate and serious action on climate change has been so slow to arrive. Our public conversation currently seems to operate on the assumption that the problem, if it is to be addressed, will be addressed in the ordinary course of business. It must be one of the chief purposes of climate change civil disobedience to change the conversation on this point. Civil disobedience has the potential to reframe the discussion from one of regular order to one of emergency measures.

If civil disobedience can change the conversation, a change in what is politically possible may not be far behind.

\section{Creating Change}

Civil disobedience can create social and political change in a variety of ways. We cannot discuss them all here. We will, however, discuss two of the most common ways.

\section{By Creating a Crisis that Puts Pressure on Decision-Makers to Act}

Decision-makers often react to pressure. The goal of some disobedients is to create sufficient pressure-sometimes through selfsuffering - to move a decision-maker to act to relieve the pressure. This was the intent of those who planned the Freedom Rides in the civil rights era. In 1961 bus terminals throughout the South were segregated by race. Some African-American leaders believed that the Kennedy administration, while somewhat friendly to the civil rights cause, nonetheless needed to feel pressure before it would act. ${ }^{17}$ The Freedom Riders, white and black, rode buses into bus terminals, with whites using black-only facilities and blacks using white-only facilities. The ultimate goal, of course, was to end segregation. The Riders were severely beaten by racist thugs; they offered no resistance, but instead willingly accepted suffering. At one point, their bus was fire-bombed, and they were nearly killed. The media covered this undeserved and unreciprocated violence, the public sympathized with the suffering of the Riders, the public put pressure on the Kennedy administration, and the administration buckled

17. James Farmer of the Congress of Racial Equality, instrumental in organizing the Freedom Rides, described the central purpose of the Rides: "...[W]e felt that we could...count upon the racists of the south to...create a crisis, so that the federal government would be compelled to enforce federal law. And that was the rationale for the Freedom Ride."

Interview by Blackside Inc. with James Farmer, Co-Founder of Congress of Racial Equality (Nov. 1, 1985) for Eyes on the Prize: America's Civil Rights Years 1954-1965 (Blackside Inc. 1987). Washington University Libraries, Film and Media Archive, Henry Hampton Collection. 
when it caused the Interstate Commerce Commission to ban segregation in terminals. ${ }^{18}$

The Freedom Rides constitute a textbook example of how civil disobedience can create pressure - and thus change-through voluntarily-accepted suffering. ${ }^{19}$

\section{By Withdrawing Cooperation}

As Erica Chenoweth and Maria Stephan explain in Why Civil Resistance Works, governments rest on pillars of support. ${ }^{20}$ Remove those pillars and the government falls. The same dynamic exists for specific policies of governments. They, too, rest on pillars of support. Remove those and the policy falls. The most significant pillar for any governmental or corporate policy is the cooperation of the public in general and the affected portion of the public in particular.

During the Vietnam War, there was significant anti-draft disobedience. Some citizens refused to register, with many going into exile in foreign countries; ${ }^{21}$ those who had registered, openly burned their draft registration cards. ${ }^{22}$ Still others refused to submit to conscription. ${ }^{23}$ A broad variety of opposition groups flourished; some of the most daring groups conducted raids on draft boards, destroying thousands of records. ${ }^{24}$ The government eventually recognized that the draft was more trouble than it was worth and ended it in the early 1970 s. $^{25}$

18. Milton Viorst, Fire In The Streets: America IN the 1960s 158 (1979).

19. For a fuller description of the disobedience of the suffrage, civil rights, and anti-war movements discussed in this Article, see Charles R. DiSalvo, The Fracture of Good Order: An Argument for Allowing Lawyers to Counsel the Civility Disobedient, 17 GA. L. REv. 109, 12425.

Another example is found in the tree sit conducted by Julia Butterfly Hill, described in Part III infra. Hill's sit worked, in large part, because her willingness to suffer through a long period of exceptionally difficult living conditions generated publicity and sympathy - both of which built up pressure on her opponent, Pacific Logging, and the government.

20. See Maria J. Stephan \& Erica Chenoweth, Why Civil Resistance Works: The Strategic Logic of Nonviolent Conflict, 33 INT'L SECURITY 7, 14 (2008).

21. Sherry Gershon Gottlieb, Hell No, We Won't Go: Resisting the Draft During THE VIETNAM WAR 1-2 (1991).

22. Lawrence M. Baskir \& William A. Strauss, Chance and Circumstance: The DrAFT, THE WAR AND THE VIETNAM GENERATION 65-66 (1978).

23. Id. at 63 .

24. Id. at 66-67; Nancy Zaroulis \& Gerald Sullivan, Who Spoke Up? American Protest Against the WAR IN Vietnam, 1963-1975, 82, 229-30, 235, 287-88 (1984).

25. Jessie Kindig, Draft Resistance in the Vietnam Era, ANTIWAR \& RADICAL Hist. PROJECT - PAC. NW., https://depts.washington.edu/antiwar/vietnam_draft.shtml [https://perma.cc/TE648Y3S] (last visited Apr. 21, 2020).

The last induction of men into the armed services took place on July 1, 1973. Draft registration ended on March 29, 1975. GotTLIEB, supra note 21, at xxi-xxii. Before the draft ended, "[w]ell over half a million men committed draft violations that ultimately could have meant five-year prison sentences." Id. at 173. 
Is there a developing analogous movement in the climate change arena today? Because pipelines run for hundreds of miles, it is impossible for pipeline operators to police their entire length. Accordingly, operators depend on the implicit agreement of the public not to interfere with the physical integrity that pipelines need to operate. There have been a few instances in which this implicit agreement has been broken. Acting not anonymously but openly, some climate activists have shut off pipeline valves $;{ }^{26}$ others have burned pipeline equipment. ${ }^{27}$ To date, these actions have merely inconvenienced, and not stopped, pipeline operators. Might a movement of hundreds or thousands of activists engaged in persistent, repeated, similar activity, however, result in the surrender of pipeline operators ${ }^{28}$

\section{Simultaneous Multiple Methods}

An academic can sit at a keyboard, set up useful categories, and offer reasonable explanations of causation. On the ground, however, things are often more complex. The two methods of change-inducing disobedience described above make the point; they are not mutually exclusive. Both types can interact with each other. Indeed, this is what happened in 1930 when Mahatma Gandhi undertook the best-known of his civil disobedience efforts. The Salt Campaign was aimed at restrictions on the manufacture and sale of salt imposed on the Indian public by the British government. ${ }^{29}$ Gandhi and his followers marched from Gandhi's ashram to the seashore ${ }^{30}$ where they made salt from sea water and then sold itall in open violation of the law. ${ }^{31}$ Hundreds of similar localized campaigns broke out. ${ }^{32}$ Before the campaign concluded, thousands withdrew their cooperation with the salt laws, with some 90,000 having been arrested. ${ }^{33}$

26. Blake Nicholson, Companies Decry 'Valve Turners' Who Shut Down Pipelines, AP NEws (Mar. 3, 2019), https://www.apnews.com/0fe28195510141eea0e407687fd49ce5 [https:// perma.cc/UAU7-A23L].

27. Jacey Fortin, 2 Dakota Pipeline Protestors Face Federal Charges Over 2017 Damage, N.Y. TIMES (Oct. 2, 2019), https://www.nytimes.com/2019/10/02/us/two-women-charged-dakota -access-pipeline.html?searchResultPosition=1 [https://perma.cc/KBB2-867P].

28. Some might call such a movement "direct action." The concept of "direct action" might aptly describe the actions of isolated activists. "Mass withdrawal of consent" might better describe disobedience that is performed by hundreds and thousands.

Barriers involved in organizing mass participation are discussed in Stephan \& Chenoweth, supra note 20 , at $34-39$.

29. Thomas Weber, On The Salt March 94 (2009).

30. Id. at 103 .

31. Id. at 389 et seq.

32. Rajmohan Gandhi, Gandhi: The Man, His People, And The Empire 311 (2008).

33. Id. at 317. 
Gandhi also generated sympathy for the cause - and pressure on the imperial government - through the self-suffering his followers endured. In May 1930, thousands of Gandhi's followers marched on the Dharasana Salt Works. ${ }^{34}$ They were clubbed mercilessly by the plant's guardswithout offering the least bit of resistance. ${ }^{35}$ There were multiple consequences from this unreciprocated government violence, including some deaths and many injuries to the disobedients, the moving coverage of the Indians' bravery by American reporter Webb Miller, and the creation of international sympathy for the Indians' cause. ${ }^{36}$

These two streams - the withdrawal of cooperation and the pressure that came from a crisis that engendered sympathy-were too much for the British. The government eventually entered into a negotiated settlement, the Gandhi-Irwin Pact. ${ }^{37}$ The British had been forced to deal with Gandhi and the rebels he led. The world now saw Gandhi and his movement differently.

Climate activists have conducted a number of their own "raids" against fossil fuel-related facilities. ${ }^{38}$ These have often been successful in bringing attention to the cause, but have had, at best, only very limited success at creating change. Climate activists would be well-advised to study the Salt Campaign. It is as clear a model for advancing the debate and creating change as there is in the entire portfolio of Gandhian civil disobedience.

\section{Principles of EfFective Civil Disobedience AgAinst Climate Change}

Some acts of civil disobedience succeed in advancing the debate and in creating change. Other acts of civil disobedience fail miserably at these missions. What accounts for the difference?

There are principles by which most successful civil disobedience abides. For disobedience intended to advance the debate, the key principle is creativity. For disobedience intended to create change, the most important principles are specificity of goal, evocativeness and media engagement, campaign integration, and timeliness of action. ${ }^{39}$ Abiding by these principles does not guarantee that an act of disobedience

34. Id. at 315 .

35. Id.

36. Id. at $315-16$.

37. Id. at 323 .

38. See, e.g., Nicholson, supra note 26.

39. Another note of realism is in order. In some instances, creativity can be important for disobedience intended to create change and, in some instances, the remaining principles can be important for disobedience intended to advance the debate. While this Article argues that creativity generally plays a heightened role in advancing the debate and the remaining principles play a heightened role in creating change, each of the principles can come into play in either arena. 
will succeed in advancing the debate or creating change. Similarly, failing to abide by some or all of these principles will not always doom an act of disobedience to failure. The world is a bit less predictable than that. One can say with a high degree of confidence, however, that abiding by these principles will greatly increase the chances that an act of disobedience will succeed and failure to abide by them will more often than not lead to failure. With this note of realism in mind, let's examine the principles.

\section{A. Creativity}

Disobedience that is routine draws little interest. It is now common for dignitaries and celebrities to get arrested in front of the White House and at the Capitol. ${ }^{40}$ This approach has been used so often that it arouses very little curiosity on the part of the public, despite the sincerity of the disobedients and the selfless sacrifice of their freedom.

In stark contrast is Julia Hills' 738-day tree sit, described below. It drew immense media attention in large part because of the novelty of its length. ${ }^{41}$

Climate activists in Wales experimented with a different novelty. In 2017, they were intent on calling the world's attention to the "need to stop burning fossil fuels." To do this they invaded an open cast coal mine and chained themselves to some of the mining equipment. What likely got this action publicity, however, was not the group's simple and common act of trespass. It was that the trespassers were dressed as canaries. The media not only reported the story and ran photos, but also quoted the activists, with one reminding the media audience that "canaries were used to alert miners to air pollution" and explaining that the activists, "as canaries, are warning that we need to take urgent action against coal to tackle air pollution and climate change."42

40. See, e.g., Caitlin O'Kane, Ted Danson Is the Latest Celebrity to Get Arrested With Jane Fonda at Weekly Climate Change Protest, CBS NEws (Oct. 25, 2019, 4:13 PM), https://www.cbsnews.com/news/jane-fonda-ted-danson-arrest-capitol-steps-during-her-weeklyclimate-change-protest-fire-drill-friday-washington-dc/ [https://perma.cc/C7S8-P74U].

41. Julia Butterfly Hill Defends California Redwoods, 1999, GLOBAL Nonviolent Action DATABASE, https://nvdatabase.swarthmore.edu/content/julia-butterfly-hill-defends-californiaredwoods-1999 [https://perma.cc/Q5SX-XDZH] (last visited Apr. 21, 2020).

42. Will Hayward, Protesters Dressed as Canaries 'Shut Down Production' at UK's Largest Open Cast Coal Mine, WaLes OnLine (Apr. 21, 2017, 1:12 PM), https://www.wales online.co.uk/news/wales-news/protesters-dressed-canaries-shut-down-12924643 [https://perma .cc/2KPE-PUGX].

When women suffragists picketed the White House, they received significant publicity in large part because such picketing was novel in 1917. Eleanor FleXner, CENTURy OF STRUGGLE: The Woman's Rights Movement in the United States 293 (1975). 


\section{B. Specificity of Goal}

When civil disobedients intend to create change, they would be well advised to aim for narrow, specific targets.

On October 30, 2017, a group of protestors sat on the London Tower Bridge, blocking vehicles from using the bridge to cross the Thames River. ${ }^{43}$ A massive traffic tie-up resulted. ${ }^{44}$ The police arrested the protestors for obstruction of a public highway. ${ }^{45}$ The protestors carried a large red banner that read: "Stop Killing Londoners, Cut Air Pollution." One bystander in the audience wrote "“[n]ine people appear to [be] protesting against something ... \& \& are blocking traffic.'

By contrast, consider a protest that occurred in $2009 .{ }^{47}$ The protestors were concerned with climate change, but their immediate target was much narrower and far more specific. In 2009, the Congress of the United States relied upon the Capitol Power Plant in Washington, D.C. for steam to provide heat and hot water for congressional buildings. ${ }^{48}$ The power

43. Sean Morrison, Tower Bridge Protest: Activists Spark Huge Traffic Jam on Thames Crossing with Anti-Pollution Demo, Evening STANDARD (Oct. 30, 2017, 2:13 PM), https://www.standard.co.uk/news/london/tower-bridge-protest-activists-shut-thames-crossingwith-antipollution-demonstration-a3671521.html [https://perma.cc/Q8LW-634N].

44. Id.

45. Id.

46. Morrison, supra note 43. Predictably, the reports of the protest in the popular media did not carry the full slate of the protestors' more specific demands. See, e.g., Morrison, supra note 43; Frederica Miller, Tower Bridge Incident: Seven arrested for obstructing public highway at air pollution protest, MYLONDON (Oct. 30, 2017, 16:52), https://www.mylondon.news/news/westlondon-news/tower-bridge-blockade-seven-arrested-13832605 [https://perma.cc/6C4J-7RC7]. One news outlet got close to one of the group's demands when it mentioned one fragment of the group's complaints; The East London Advertiser reported that the group protested that "the Mayor of London's proposed expansion of an 'Ultra Low Emissions' zone out to the North Circular and South Circular main routes "doesn't go far enough" to tackle London's air pollution." Mike Brooke, Protestors block Tower bridge causing traffic jam - in protest of traffic pollution, EAST LONDON ADVERTISER (Oct. 30, 2017, 11:27 PM), https://www.eastlondonadvertiser.co.uk/news/ protesters-block-tower-bridge-causing-traffic-jam-in-protest-at-3574332

[https://perma.cc/6C3L-5CV5]. The group's detailed agenda was buried deep in the group's Facebook page. Funeral Procession: Stop Killing Londoners Cut Air Pollution, https://www.facebook.com/events/1459947787414590/?acontext=\%7B\%22source\%22\%3A3\% 2C\%22source_newsfeed_story_type $\% 22 \% 3 \mathrm{~A} \% 22$ regular $\% 22 \% 2 \mathrm{C} \% 22$ action_history $\% 22 \% 3 \mathrm{~A}$ $\% 22[\% 7 \mathrm{~B} \% 5 \mathrm{C} \% 22$ surface $\% 5 \mathrm{C} \% 22 \% 3 \mathrm{~A} \% 5 \mathrm{C} \% 22$ newsfeed $\% 5 \mathrm{C} \% 22 \% 2 \mathrm{C} \% 5 \mathrm{C} \% 22$ mechanism $\% 5 \mathrm{C} \% 22 \% 3 \mathrm{~A} \% 5 \mathrm{C} \% 22 \mathrm{feed} \_s t o r y \% 5 \mathrm{C} \% 22 \% 2 \mathrm{C} \% 5 \mathrm{C} \% 22 \mathrm{extra}$ data $\left.\% 5 \mathrm{C} \% 22 \% 3 \mathrm{~A}[] \% 7 \mathrm{D}\right] \% 22$ $\% 2 \mathrm{C} \% 22 \mathrm{has} \_s o u r c e \% 22 \% 3 \mathrm{Atrue} \% 7 \mathrm{D} \&$ source=3\&source_newsfeed_story_type=regular\&acti on_history $=[\% 7 \mathrm{~B} \% 22$ surface $\% 22 \% 3 \mathrm{~A} \% 22$ newsfeed $\% 22 \% 2 \mathrm{C} \% 22$ mechanism $\% 22 \% 3 \mathrm{~A} \% 22 \mathrm{fee}$ d_story $\% 22 \% 2 \mathrm{C} \% 22$ extra_data $\% 22 \% 3 \mathrm{~A}[] \% 7 \mathrm{D}] \&$ has_source= $1 \& \mathrm{fref}=\mathrm{nf} \quad$ [https://perma.cc/ TM5B-DDSK].

47. Bryan Walsh, Despite Snow — and Irony - a Climate Protest Persists, TIME (Mar. 3, 2009), http://content.time.com/time/health/article/0,8599,1882700,00.html [https://perma.cc/ R7CT-7LJT].

48. Congress to Stop Using Coal in Power Plant, Associated Press, http://www.nbc news.com/id/30561554/ns/us_news-environment/t/congress-stop-using-coal-power-plant/ 
plant was fueled in part by coal, ${ }^{49}$ notorious, of course, for its contribution to the climate crisis. A coalition of more than forty groups planned mass civil disobedience at the plant's gates to protest its use of coal, ${ }^{50}$ the activists intended to block the gates to the plant. ${ }^{51}$ Before the protestors arrived, Congressional leaders "announced that they would convert the plant to run entirely on natural gas . .."52 One of the organizers of the protest, author and activist Bill McKibben, stated: "“It sounds like we're making progress before we even get there.",53

Why did the London action come up short and the Washington action succeed?

Decision-makers react to pressure. When protestors apply all their might to one specific political point, the pressure on that point is great, and as a result decision-makers are more likely to react. When protestors apply their might to a broad band of points, pressure is diluted and the effect on any one point is quite modest. Indeed, it is almost non-existent. The Capitol Power Plant protestors demanded a very specific change and thus were able to apply significant pressure. The apparent target of the London Bridge protestors was very diffuse and unspecific_- "air pollution." At least one close observer wasn't able to understand even that purpose. Contrast the initial ambiguity surrounding the London Bridge protest with the focused approach of the Capitol Power Plant protest. The Capitol Power Plant protest got results.

The narrower and more specific the goal, the more likely success will follow. ${ }^{54}$

[https://perma.cc/YD8B-RNSV] (last updated May 4, 2019).

49. Id.

50. Advisory: Biggest Ever Civil Disobedience on Climate at Congressional Power Plant, GREENPEACE (July 6, 2010), https://www.greenpeace.org/usa/news/1000-already-signed-up-topar/ [https://perma.cc/ASL3-FQPR].

51. Walsh, supra note 47.

52. Eoin O'Carroll, Do Climate Protests Work?, Christian SCI. Monitor (Mar. 6, 2009), https://www.csmonitor.com/Environment/Bright-Green/2009/0306/do-climate-protests-work [https://perma.cc/554T-TBNU].

53. Id. By 2011, the plant was using only $5 \%$ coal in its fuel mix. The plant, however, did not go forward with the plan to convert completely to natural gas, burning diesel fuel oil instead. "We worked to figure out a way to get around the issue of coal," said Drew Hammill . . "But it is a futile effort until you get rid of the Republican majority. They do not believe in the word 'green." Erin Banco, Cut Emissions? Congress Itself Keeps Burning a Dirtier Fuel, N.Y. TIMES (Aug. 8, 2013), https://www.nytimes.com/2013/08/09/us/politics/just-across-town-a-test-ofobamas-emissions-goals.html [https://perma.cc/F7SH-CDBM].

54. In the example given here, change is the goal. When a change to the conversation is the goal, specificity remains important, but, perhaps, it is not as pivotal. More specificity likely advances the debate more effectively than less specificity, but virtually any action against climate change keeps the issue before the public and advances the conversation. 


\section{Evocativeness and Media Engagement}

Whether the goal is to advance the debate or to create change, the potential of an act of disobedience to reach its goal is immeasurably enhanced when the disobedience evokes a sympathetic reaction from the public. Public sympathy usually translates, at a minimum, into intensified public conversation and, oftentimes, increased pressure on decisionmakers, as well.

Sympathy, however, does not come cheap.

It requires suffering.

The following three instances of suffering, briefly noted earlier, were quite effective in evoking public sympathy and subsequent media attention.

\section{Women's suffrage}

In the early part of the twentieth century, women did not have the right to vote in federal elections or in elections held in the majority of states. ${ }^{55}$ To protest this inequality, American suffrage activists, starting in January 1917 , engaged in what was then a novelty in this country: picketing. ${ }^{56}$ Believing that the support of the President was the key to passage of a voting rights amendment to the Constitution in Congress, women picketed Woodrow Wilson's White House, carrying banners in favor of women's rights. ${ }^{57}$

55. The Women's Rights Movement, 1848-1920, Hist., ART \& ARChIVES, U.S. House OF REPRESENTATIVES, https://history.house.gov/Exhibitions-and-Publications/WIC/HistoricalEssays/No-Lady/Womens-Rights/ [https://perma.cc/H2LK-J4PR] (last visited Apr. 22, 2020) (“[B]efore 1910 only . . . four states allowed women to vote."); see also CoONEY, supra note 12, at 85 ("Men and women vote on equal terms for all officers, even for presidential electors, in four of the United States.").

56. Today in History - August 28: Picketing for Suffrage, LIB. OF ConG., https://www.loc.gov/item/today-in-history/august-28/ [https://perma.cc/NW7H-4YU2] ("Daily picketing began on January 10, 1917.”) (last visited Apr. 22, 2020).

57. Professor Christine Lunardini explains the politics of the time:

World War I . . formed the backdrop for a triangle that had been developing since Alice Paul left NAWSA [National American Woman Suffrage Association] . . . a triangle consisting of the NWP [National Women's Party], NAWSA, and [President] Woodrow Wilson ... NAWSA, led by the politically canny Carrie Chapman Catt, struck a note of conciliatory cultivation with Wilson. By her criticism of the activities of Paul's NWP, Catt's NAWSA became, in Wilson's view particularly, the moderates . . . Increasingly, compelled by events generated by the militants, Wilson made political concessions which he then attributed to the deserving nature of reasonable women, epitomized by the NAWSA suffragists.

Christine A. Lunardini, From Equal Suffrage to Equal Rights: Alice Paul and the NATIONAL WOMAN's PARTY, 1910-1928, 123 (1986). 
Eventually and quite pointedly, the banners taunted President Wilson by bearing his own words in praise of democracy. ${ }^{58}$ Male onlookers, some enraged by the notion of female suffrage and others enraged by the audacity of women protesting against the President during war time, ${ }^{59}$ repeatedly attacked the women, roughing them up and tearing their banners apart. ${ }^{60}$ Women were "kicked, dragged, battered, and bruised." 61 Even the police joined in the attacks against the picketers. ${ }^{62}$ At one point, someone fired a shot into the women's headquarters. ${ }^{63}$ The women, led by the Quaker Alice Paul, persistently refrained from counter-attacking and remained nonviolent. ${ }^{64}$

The government eventually prosecuted the women for "obstructing the traffic," a patently frivolous charge intended to get the women out of public view. ${ }^{65}$ Upon their conviction, some women, including Alice Paul, were sent to the notorious Occuquan workhouse in Virginia. ${ }^{66}$ There, they were mistreated. ${ }^{67}$ Prison officials allowed non-suffrage prisoners to beat suffrage prisoners. ${ }^{68}$ The food, infested with mealworms, made prisoners sick. ${ }^{69}$ Rats ruled the cells. ${ }^{70}$ Lucy Burns, with Alice Paul, a cofounder of the National Women's Party (the party leading the picketing effort), was "beaten, stripped, and locked up in solitary confinement.",71

58. The United States entered World War I in April 1917. The women quoted Wilson's remarks that explained the importance of the war effort for preserving democracy. CoONEY, supra note 12, at 343 ("The messages on the pickets' banners . . . included quotes drawn from President Wilson's own speeches").

59. CoONEY, supra note 12, at 343. Some considered the women's actions treasonous. See LUNARDINI, supra note 57, at 126.

60. CoONEY, supra note 12 , at 343,351 . Banners and flags torn apart numbered in the hundreds. COONEY, supra note 12 , at 350.

61. COONEY, supra note 12 , at 351.

62. FLEXNER, supra note 42 , at 286.

63. LUNARDINI, supra note 57, at 128.

64. Linda J. LuMSDEN, RAMPANT Women: SufFRAgists AND the Right OF AsSEMbly 114-15 (1997) ("The women never resorted to violence despite the many attacks upon them. In fact, the one truly original contribution Americans made to suffrage campaigning was their nonviolent political protests. The decision to invoke nonviolent political protest was not only a canny publicity stroke but also a testament of faith and courage that gave the picketers unassailable moral strength. The Wilson administration learned the hard way about the moral invincibility of nonviolent protest, as would British colonialists in India and segregationists in the American South."); see also Linda Ford, Alice Paul and the Politics of Nonviolent Protest, in Votes For Women: The Struggle for SufFrage Revisited 174, 179 (Jean H. Baker ed., 2002).

65. COONEY, supra note 12 , at 356.

66. LUNARDINI, supra note 57, at 132.

67. LUNARDINI, supra note 57, at 134-35.

68. LUNARDINI, supra note 57, at 135.

69. LUNARDINI, supra note 57 , at 131.

70. LUNARDINI, supra note 57, at 131.

71. COONEY, supra note 12, at 356. 
In the fall of 1917, Paul was sentenced to seven months in the Washington, D.C. jail. ${ }^{72}$ There she and suffragist Rose Winslow "decided upon the hunger strike, as the ultimate form of protest left usthe strongest weapon left with which to continue within the prison our battle against the Administration." 73 Paul was thereafter locked up in what was called the "psychopathic" section of the prison where "she was deprived of sleep, harassed, interrogated, and threatened with commitment to the insane asylum if she continued." 74 Prison authorities responded by brutally force-feeding Paul, Winslow, and other women, shoving tubes down their throats while prison guards held the women down. ${ }^{75}$ This force-feeding, which sometimes resulted in vomiting, took place for three weeks, three times a day. ${ }^{76}$ Faced with women who would not back down, the government did. "[A]ll the prisoners[,]" records Doris Stevens, "were unconditionally released."77

The picketing, the harsh treatment of the women in prison, and the hunger strikes succeeded in greatly intensifying the conversation about the right of women to vote at a time when war news threatened to eclipse the suffrage effort. ${ }^{78}$ Throwing middle-class women in jail and mistreating them while they were detained played right into the suffragists' hands, generating what Professor Christine Lunardini calls, an "extraordinary amount of publicity."79 Newspapers around the country criticized the arrests of the women, ${ }^{80}$ and featured a Congressman's criticism of the Administration, who scolded Wilson for not stopping the arrests. ${ }^{81}$

Newspaper coverage helped create the pressure necessary to bring President Wilson, and finally Congress, to the women's side. ${ }^{82}$ The suffering the women endured on the picket line and in prison resulted in widespread newspaper coverage of the women's cause, ${ }^{83}$ which in turn

72. COONEY, supra note 12 , at $356-57$.

73. COONEY, supra note 12, at 357.

74. COONEY, supra note 12 , at 357 .

75. COONEY, supra note 12 , at 361.

76. See COONEY, supra note 12, at 361; LunARDINI, supra note 57, at 133-34.

77. DORIS STEVENS, JAILED FOR FREEDOM 241 (1920).

78. See LUNARDINI, supra note 57, at 126; see also LUMSDEN, supra note 64, at 134.

79. LUNARDINI, supra note 57, at 126-27.

80. LUMSDEN, supra note 64, at 127.

81. LUNARDINI, supra note 57 , at 128-29.

82. COONEY, supra note 12, at 363; LUMSDEN, supra note 64, at 134, 139-40.

83. Suffrage activist Doris Stevens later recounted the reaction of the suffrage movement to the jailing of its leader, Alice Paul. Forty-one women picketed the White House in support of suffrage and in protest of Paul's arrest. The forty-one were arrested, but released, in Stevens' estimation because the government "could not stand the reaction which was bound to come from imprisoning them." Stevens' quotes Philadelphia's North American: "There was no disorder. The crowd waited with interest and in a noticeably friendly spirit to see what would happen. There were frequent references to the pluck of the silent sentinels." DORIS STEVENS, JAILED FOR 
won the women "sympathy and support from diverse segments of the American population." 84 This public sympathy put pressure on Wilson. ${ }^{85}$

The suffragists' suffering paid off when Wilson was finally forced to act in a decisive way. ${ }^{86}$ On January 9,1918 , Wilson met with a group of House members who were undecided about the federal amendment. ${ }^{87}$ Wilson advised them to vote for it. ${ }^{88}$ Two days later, the House passed the amendment by the necessary two-thirds margin, with not a vote to spare. ${ }^{89}$ All twelve of the representatives who had met with Wilson voted for passage. ${ }^{90}$

Several publications including the New York Times and the Washington Post editorialized that success was due to Wilson's last-minute endorsement. The goal of the picketing campaign... had been to convert Wilson to federal suffragism.... Wilson's public endorsement of the amendment in January 1918 was crucial. Suffrage had reached a major turning point. ${ }^{91}$

After further interventions by Wilson at both the federal and state level, the proposed amendment finally became law on August 26, 1920. ${ }^{92}$

Earlier, Chief Justice Walter Clark of North Carolina congratulated Alice Paul and her party on their impending success with these words: "There were politicians, and a large degree of public sentiment, which could only be won by the methods you adopted . . . . It is certain that, but for you, success would have been delayed for many years to come." 93

FREEDOM 194-95 (1920). Indeed, Paul's jailing "garnered public sympathy and support for suffrage." Debra Michals, Alice Paul, Nat'L Women's Hist. Museum, https://www.womenshistory.org/education-resources/biographies/alice-paul (last visited July 30, 2019).

84. LuMSDEN, supra note 64, at 126; see also Linda G. Ford, IRON-JAWED ANGELS: THE Suffrage Militancy of the NAtional Woman's PARTy 1912-1920 172 (1991) (“Government violence just gave nonviolent woman suffrage protestors added public visibility and increased sympathy, even among Congressmen.").

85. LUNARDINI, supra note 57, at 136-38; see also LUMSDEN, supra note 64, at 124 (explaining that Alice Paul was aware of the sympathy-generating nature of the suffragists' actions).

86. The force of the pickets' suffering was not the only pressure bearing down on Wilson and the Congress. See Eleanor Flexner, Century of Struggle: The Women's Rights Movement IN THE United STATES 297-301 (1975).

87. LUNARDINI, supra note 57 , at 140.

88. LUNARDINI, supra note 57 , at 140.

89. LUNARDINI, supra note 57, at 140.

90. LUNARDINI, supra note 57, at 140.

91. LUNARDINI, supra note 57 , at 140 .

92. Christine A. Lunardini \& Thomas J. Knock, Woodrow Wilson and Woman Suffrage: A New Look, 95 PoL. ScI. Q. 655, 668-70 (1980).

93. LUNARDINI, supra note 57, at 149. 


\section{The Salt Campaign}

In 1930, Gandhi's followers, schooled in nonviolence, marched on the Dharasana Salt Works in protest of the British monopoly on saltmaking. ${ }^{94}$ The Salt Works were "guarded by four hundred native Surat [p]olice.... Half a dozen British officials commanded them. The [p]olice carried lathis - five foot clubs tipped with steel." of this confrontation of nonviolence with violence drew a correspondent for the United Press, Webb Miller, to Dharasana $;{ }^{96}$ there he witnessed first-hand the brutality visited upon the disobedients. ${ }^{97}$ His reporting, carried in over 1,300 newspapers, ${ }^{98}$ described the suffering of Gandhi's followers:

Suddenly, at a word of command, scores of native police rushed upon the advancing marchers and rained blows on their heads with their steel-shod lathis. Not one of the marchers even raised an arm to fend off the blows. They went down like ten-pins. From where I stood I heard the sickening whacks of the clubs on unprotected skulls. The waiting crowd of watchers groaned and sucked in their breaths in sympathetic pain at every blow.

Those struck down fell sprawling, unconscious or writhing in pain with fractured skulls or broken shoulders. In two or three minutes the ground was quilted with bodies. Great patches of blood widened on their white clothes. The survivors without breaking ranks silently and doggedly marched on until struck down. When every one of the first column had been knocked down stretcher-bearers rushed up unmolested by the police and carried off the injured to a thatched hut which had been arranged as a temporary hospital. Then another column formed while the leaders pleaded with them to retain their self-control. They marched slowly toward the police. Although every one knew that within a few minutes he would be beaten down, perhaps killed, I could detect no signs of wavering or fear. They marched steadily with heads up, without the encouragement of music or cheering or any possibility that they might escape serious injury or death. The police rushed out and methodically and mechanically beat down the second

94. Thomas Weber, On the Salt March 488, et seq. (2009).

95. Webb Miller, I Found No Peace 193 (1936)

96. $I d$.

97. $I d$. at 192 , et seq.

98. Thomas Weber, On the Salt March: The Historiography of Mahatma Gandhi's TO DANDI 456 (2009). Miller's reporting was also read into the Congressional Record and later printed as a leaflet, more than 250,000 copies of which were distributed. Id. 
column. There was no fight, no struggle; the marchers simply walked forward until struck down. There were no outcries, only groans after they fell. There were not enough stretcher-bearers to carry off the wounded; I saw eighteen injured being carried off simultaneously, while forty-two still lay bleeding on the ground awaiting stretcher-bearers. The blankets used as stretchers were sodden with blood. ${ }^{99}$

The British unsuccessfully attempted to censor Miller's reports-and with good cause. ${ }^{100}$ An objective reader could not help but have sympathy for the cause of Indian independence after reading Miller's work. Illustrative of this point is an excerpt from an uncensored piece Miller had in the New York Telegram of June 11, 1930:

In 18 years of reporting in 22 countries, during which I have witnessed innumerable civil disturbances, riots, street fights, and rebellions, I have never witnessed such harrowing scenes as at Dharsana. The western mind can grasp violence returned by violence, can understand a fight, but is, I found, perplexed and baffled by the sight of men advancing coldly and deliberately and submitting to beating without attempting defense. Sometimes the scenes were so painful that I had to turn away momentarily. One surprising feature was the discipline of the volunteers. It seemed they were thoroughly imbued with Gandhi's nonviolence creed, and the leaders constantly stood in front of the ranks imploring

99. Webb Miller, I Found No PeACe: The Journal of a Foreign Correspondent 1956 (1936). Miller went on to note: "At times the spectacle of unresisting men being methodically bashed into a bloody pulp sickened me so much that I had to turn away." Id. at 194.

Miller also described to the American public a later phase of the raid:

The Gandhi men altered their tactics, marched up in groups of twenty-five and sat on the ground near the salt pans, making no effort to draw nearer .... [T]he beating recommenced ... . Bodies toppled over in threes and fours, bleeding from great gashes on their scalps. Group after group walked forward, sat down, and submitted to being beaten into insensibility without raising an arm to fend off the blows. Finally the police became enraged by the nonresistance . . . and commenced savagely kicking the seated men in the abdomen and testicles. The injured men writhed and squealed in agony .... The police then began dragging the sitting men by the arms or feet, sometimes for a hundred yards, and throwing them into ditches .... [A] policeman dragged a Gandhi man to the ditch, threw him in, then belabored him over the head with his lathi. Hour after hour stretcherbearers carried back a stream of inert, bleeding bodies . . . . By eleven the heat reached 116 in the shade and the activities of the Gandhi volunteers subsided. I went back to the temporary hospital to examine the wounded . . . I counted 320 injured, many still insensible with fractured skulls, others writing in agony from kicks in the testicles and stomach .... [T]wo had died."

Id. at $195-96$.

100. WeBER, supra note 98 at 450, 455-56. 
them to remember that Gandhi's soul was with them. ${ }^{101}$

Later, when Gandhi's Mumbai followers were also beaten, American reporter Negley Farson was there to record that episode of suffering. ${ }^{102}$ The influential Christian Century editorialized about Farson's reporting and its effect:

After a delay, the censors have permitted [a] news dispatch by Mr. Negley Farson, of the Chicago Daily News, to reach this country. Mr. Farson speaks of the effect which the sights he is witnessing in India are having on him. A veteran newspaper man, yet this clubbing of non-resisting people, whose wrongdoing it is that they desire national freedom, has, in his words, 'made me physically ill' and 'wrung my heart.' A reading of his report will have the same effect on many Christians of the west, thousands of miles though they may be from Bombay .... The thing that is happening in Bombay is so awful that words fail to describe it. Western civilization is beating itself to death with the clubs of the Bombay police. ${ }^{103}$

The Chicago Tribune carried the work of journalist Charles Dailey from Bombay, who reported on June 21, 1930 that "[t]he savagery of the police attack exceeded any since the Nationalist revolt developed. . . . Five hundred policemen, some mounted, took part in the charges, using clubs. Many natives fell under the horses' hoofs." 104

The newspaper reports filed by Miller, Farson, and Dailey brought the cause of Indian independence to the attention of Western readers, ${ }^{105}$ and, in doing so, they created sympathy in the West and elsewhere for

101. Manoranjan Jha, Civil Disobedience and After: The American Reaction to Political DeVelopments in India DuRING 1930-1935, 114-15 (1973) (quoting N.Y. Telegraph, June 11, 1930).

102. Charles Chatfield, The Americanization of Gandhi: Images of the Mahatma 257 (1976).

103. "Is Western Civilization to Commit Suicide?," The Christian Century 1930, https://www.google.com/books/edition/The_Christian_Century/yGs5AQAAIAAJ?hl=en\&gbpv $=1 \& \mathrm{bsq}=$ censors [https://perma.cc/3FUD-HE3P]. The full text of Farson's report in the Chicago Daily News of June 10, 1903, can be found in Gene SharP, GandHI WiELDS THE Weapon OF Moral Power: Three CASe Histories 185 (1960).

104. Charles Dailey, Police Crack Heads of 500 in India Riot, CHI. TrIB., June 22, 1930, reprinted in 71 Cong. Rec. 73, 218 (July 17, 1930).

105. See Sean Scalmer, Gandhi in the West: The Mahatma and the Rise of Radical PROTEST 46 (2011) ('Some Europeans confessed that they had become 'physically ill' at the sight of 'this clubbing of non-resisting people.' Others wrote of 'European women turning away with averted eyes, obviously feeling faint.' The journalist attached to the Manchester Guardian admitted that the whole thing was 'a very disagreeable sight', especially for 'the squeamish, like myself'."'). 
the campaign for freedom from British rule. ${ }^{106}$ Moreover, because the Salt March had been reported on, it "demonstrated to the world the nearly flawless use of a new instrument of peaceful militancy."107

\section{Freedom Rides}

The Freedom Riders offered no resistance to racist hoodlums who attempted to injure and kill them as they rode buses throughout the South in protest of racially segregated bus terminals. ${ }^{108}$ News reports brought dramatic images of the injured victims into American living rooms. In one especially iconic example of this, reporter Robert Schackne of CBS News interviewed a Freedom Rider, Jim Peck, on national television. ${ }^{109}$ Peck had been brutally attacked and knocked unconscious. ${ }^{110}$ Peck appeared on television screens in homes all across the country, heavily bandaged, and bearing multiple head wounds from his severe beating. ${ }^{111}$ One can only imagine the sympathy Peck evoked when he spoke through a mouth that only recently had a half-dozen teeth knocked from it.

More moving yet was the sight and sound of another badly beaten Freedom Rider, Jim Zwerg, who spoke to the nation, again via CBS News, from his hospital bed. ${ }^{112}$ Zwerg's speech was slow and labored, but filled with the emotion of one completely dedicated to his cause:

[S] egregation must be stopped. It must be broken down. Those of us who are on the Freedom Rides will continue. I'm not sure if I'll be able to, but we are going on to New Orleans no matter what happens. We are dedicated to this. We will take hitting. We'll take beating. We're willing to

106. Gandhi scholar, Thomas Weber, concludes that Webb Miller's "reports helped to swing the pendulum of moral righteousness from the side of the British to that of the nationalists." WEBER, supra note 98, at 499. Of Miller's, Farson's, and Dailey's reports, Manranjan Jha writes that they "and the wide publicity given to them made deep impressions on the American mind ...." JHA, supra note 101, at 116.

The relationship between the suffering of disobedients and the effect of that suffering on observers, is discussed in detail in Brian Martin, Justice IGNiTED: The DynAmics of BACKFIRE (2007). Gandhi taught that self-suffering directly changes the heart of the opponent. Thomas Weber differs; he demonstrates that while self-suffering does convert the opponent, it does not do so directly, but rather by changing the views of relevant third parties, whose changed views then lead to a change in the views of the opponent. Thomas Weber, "The Marchers Simply Walked Forward until Struck Down": Nonviolent Suffering and Conversion, 18 PEACE \& CHANGE 267, 282 (1993).

107. WeBER, supra note 98, at 534 (quoting E.H. Erikson).

108. See generally RAYMOND ARSENAULT, FREEDOM RIDERS (2006).

109. Eyes on the Prize: Ain't Scared of Your Jails: 1960-1961, at 30:19 (Blackside Inc. Feb. 4, 1987), https://www.youtube.com/watch?v=aXG9lqr6qk4 [https://perma.cc/HY39-DDJD].

110. Id.

111. $I d$.

112. Juan Williams, Eyes on the Prize: America’s Civil Rights Years, 1954-1965 155 (1987). 
accept death. But we are going to keep coming until we can ride [from] anywhere in the South to anyplace else in the South, as Americans, without anyone making any comment. ${ }^{113}$

In addition to forcing the Kennedy Administration to enact regulations banning segregation in bus terminals, the Freedom Rides helped create momentum for the passage into law of the Voting Rights Act. ${ }^{114}$

In each of the three previous instances, the unmerited suffering of the disobedients attracted media attention-newspapers in the cases of the suffrage campaigners and the Indian independence advocates, and newspapers, radio, and television in the case of the Freedom Riders. The media made it certain that the public could not easily turn away from the suffering of the disobedients. When people bravely and willingly endure violence without responding in kind, public sympathy and curiosity are aroused. The public is very naturally led to ask: "Why are these people suffering? What is their cause?" Curiosity leads to sympathy. Sympathy leads to pressure on decision-makers. Pressure on decision-makers leads to change - the passage of the Nineteenth Amendment, the signing of the Gandhi-Irwin pact, ${ }^{115}$ the issuance of regulations outlawing segregation in bus terminals, the enactment the Voting Rights Act.

Gandhi put it best:

... [T] hings of fundamental importance to the people are not secured by reason alone but have to be purchased with their suffering. Suffering is the law of human beings; war is the law of the jungle. But suffering is infinitely more powerful than the law of the jungle for converting the opponent and opening his ears, which are otherwise shut to the voice of reason.... [I]f you want something really important to be done you must not merely satisfy the reason, you must move the heart also. The appeal of reason is more to the head, but the penetration of the heart comes from suffering. It opens up the inner understanding in man. Suffering is the badge of the human race, not the sword."116

Thirty years later, in writing to Jim Zwerg, Martin Luther King echoed

113. Id.

114. Jonathan C. Augustine, The Theology of Civil Disobedience: The First Amendment, Freedom Riders, and the Passage of the Voting Rights Act, 21 S. CAL. InTERDISC. L. J. 255, 256 (2012).

115. The particular provisions of the Pact disappointed many of Gandhi's followers. Gandhi's victory, however, was in forcing the British to negotiate with him and his movement. For this point and for a discussion of the reception the Pact received, see WEBER, supra note 98, at $521-22$.

116. Mahatma Gandhi, The Birmingham Visit, 45 Young India 333, 341 (1931). 


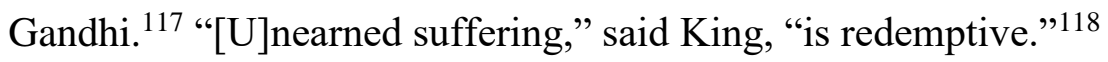

\section{Campaign Integration}

In most social movements, patience is in short supply. When the grievance is well-founded, and the grievants long-suffering, one should expect to hear voices like that of Martin Luther King, Jr. telling the opposition "why we can't wait."

King, however, was still a Gandhian ${ }^{120}$ who understood that civil disobedience does not have first place in a campaign for change. ${ }^{121}$ Joan Bondurant opens her well-known study of Gandhi's philosophy of conflict with this observation made by Gandhi: "Satyagraha ${ }^{122}$ is not predominantly civil disobedience, but a quiet and irresistible pursuit of truth.... On the rarest occasions it becomes civil disobedience. But conscious and willing obedience must ... precede it."123

There is a great deal of practical wisdom supporting Gandhi's position that a social movement must not make civil disobedience its first move. When a movement aims at changing a governmental policy, its best hope for success often rests in bringing the pressure of public opinion to bear upon governmental decision-makers. A fundamental change in public opinion on an issue that is controversial in its time usually must be brought about by a step-by-step process. ${ }^{124}$ If a social movement immediately engages in civil disobedience, it can be dismissed as not serious. The ground must be prepared. The public must be educated about the issue. The public must see that the proponents of change have tried all the usual and lawful means of creating change-reasoning, voting, lobbying, petitioning, organizing, negotiating, litigating. ${ }^{125}$ The public

117. Tony Gonzalez, Jim Zwerg: Nashville's Accidental Civil Rights Advocate, THE TENNESSEAN, July 28, 2013.

118. Id.

119. Martin Luther King, JR., Why We CAN'T WAit x-xi (1964).

120. "I owe a great deal to Mahatma Gandhi for my own commitment to nonviolence. I would say that we gained the operative technique for this movement from the great movement that took place in India." Mary King, Mahatma GANDHI AND MARTin Luther King JR: The Power of Nonviolent Action 210 (1999) (quoting Martin Luther King, Jr., Nat'l Press Club luncheon (Aug. 22, 1962)).

121. Id. at 78 .

122. Literally translated, "truth force." Satyagraha can best be understood as the Gandhian nonviolent technique of social change. See JoAn V. Bondurant, Conquest of Violence: The GANDHIAN Philosophy of CONFLICT 16 (rev. ed. 1967).

123. Id. at $\mathrm{v}$.

124. Bondurant describes this as "[p]rogressive advancement of the movement through steps and stages determined to be appropriate within the given situation. Decision as to whether to proceed to a further phase of the satyagraha must be carefully weighed in light of the everchanging circumstance. ..." Id. at 38 .

125. "[D]irect action is to be launched only after all other efforts to achieve an honorable settlement have been exhausted." Id. at 38. Both Bondurant and King list the steps one must take 
must be made to understand that the proponents of change have first tried all the conventional methods and that they have been frustrated at every turn before resorting to law-breaking. Only when the perception takes root in the public consciousness that all reasonable alternatives have been employed without success by the proponents of change will the public be prepared to be moved by civil disobedience.

Illustrative of the effectiveness of making civil disobedience a welltimed phase of a campaign, rather than the leading edge-or the entirety - of the campaign, is the campaign that occurred in Australia in the nineteen-eighties to save the Franklin River.

Tasmania is an island off the southern coast of mainland Australia. The Franklin River is a wild river that flows through the mountains of western Tasmania. ${ }^{126}$ Tasmania's powerful Hydro Electric Commission (HEC) proposed damming the Franklin and Gordon Rivers to facilitate the generation of electric power. ${ }^{127}$ (The Franklin flows into the Gordon). ${ }^{128}$ The dam threatened to flood the area through which the Franklin ran and to thereby destroy most of the river by turning it into a large artificial lake. ${ }^{129}$

In response to this threat to the Franklin, conservationists mounted a campaign to stop the dam. ${ }^{130}$ The Tasmanian Wilderness Society (TWS), led by a Tasmanian physician, Dr. Bob Brown, was a prominent, though not the exclusive, force in the campaign. ${ }^{131}$

The first stage of the campaign to save the Franklin was an effort to educate the public and decision-makers about the threat to the Franklin. ${ }^{132}$ This aspect of the movement took several forms. The TWS "organized an ambitious series of rafting trips down part of the river" for politicians and members of the media, including a film-maker, to show them "what would be lost if the river were flooded." 133 Archaeologists who explored an aboriginal cave that would be flooded by HEC demonstrated that at "the height of the last Ice Age, [the cave] was home to the southernmost

before engaging in direct action. See id. at 40; Letter from Birmingham Jail in KING, supra note 120 , at 78 .

126. Writing in 1981, Bob Connolly described the Franklin as having "no towns or houses by its banks; no sheep graze nearby; no sewers, industrial drains or suburban gutters empty into it; there are no dams across it ... no roads or railway lines run along it. There are no rivers like the Franklin left in Australia." Bob Connolly, The Fight for the Franklin: The Story of Australia’s LAST WILD River 3 (1981).

127. Id. at 18 .

128. $I d$.

129. $I d$. at 7,18 .

130. Id. at 7-8.

131. Id. at 10 .

132. Id. at 7-8.

133. Id. 
humans on earth", and promoted media accounts of their findings. ${ }^{134}$ The campaign to save the Franklin expanded to include "public meetings, slide shows, pamphlets, colour publications, [and] guide books;" TWS activists also generated "letters and articles for the press, appeared on television, and spoke to politicians. ... More and more people spoke out against the dam, calling on the [Tasmanian] state government to protect the river." 135 The TWS and Brown staged a lawful rally and lawful protest walk in the capital, Hobart. ${ }^{136}$ It was the largest public rally in Tasmanian history and the largest conservation rally ever in all of Australia. ${ }^{137}$

TWS organized a petition that collected some 40,000 signatures. ${ }^{138}$ It enjoyed the support of the well-known violinist, Yehudi Menuhin, who helped launch a color booklet showing pictures of the Franklin and Gordon rivers. ${ }^{139}$ TWS conducted a poll of Tasmanians that showed they "overwhelmingly wanted the Franklin saved. . .."140

The results of the pre-civil disobedience portion of the campaign were, at best, mixed; the campaign did generate favorable media reports, but achieved less than full political success as the effort to save the Franklin was stymied by the state government in Tasmania. ${ }^{141}$ After an initial victory by the conservationists, the pro-dam forces countered and the issue was left momentarily undecided. ${ }^{142}$

The next phase of the campaign to stop the destruction of the Franklin short of civil disobedience occurred at the electoral level in Tasmania. ${ }^{143}$ Brown stood for office ${ }^{144}$ and the conservationists urged a "no dams" vote in a Tasmanian plebiscite. Brown lost and while a third of the electorate scrawled "No Dams" across their ballots, a majority of Tasmanian voters favored building a dam. ${ }^{145}$ Nonetheless, some considered the elections

134. Billy Griffiths, Deep Time Dreaming: Uncovering Ancient Australia 213 (2018).

135. William J. Lines, The Franklin River Campaign - Part 1 - The Beginnings of Australia's Environmental Movement, WILDERNESS SOC'Y, https://web.archive.org/web/ 20110302033105/http://www.wilderness.org.au/campaigns/forests/frankin-river-campaign-part1 (last updated July 23, 2010).

136. ConNOLLY, supra note 126 , at 125.

137. CONNOLLY, supra note 126, at 125 .

138. Greg Buckman, TAsmania’s Wilderness Battles: A History 39 (2008).

139. $I d$.

140. $I d$.

141. ConNOLly, supra note 126, at 128-29.

142. ConNOLly, supra note 126 , at 128.

143. See Geoff Law, The River Runs Free: Exploring and Defending Tasmania's WILDERNESS, Ch. 4 (2008).

144. See William J. Lines, The Franklin River Campaign - Part 2 - The Franklin - Part of the World's Cultural Heritage, WILDERNESS SOC'Y, https://web.archive.org/web/20110308063 426/http://www.wilderness.org.au/campaigns/forests/franklin-river-campaign-part2 (last updated June 24, 2010) [hereinafter Lines, Part 2].

145. See Lines, Part 2, supra note 144. 
results a significant win for the conservationists that "made people around the country sit up and take note of the Franklin campaign.... The referendum gave TWS a much higher profile. ..."146

The conservationists, realizing that the dam would have to be stopped at the national, rather than state, level, expanded the campaign to the mainland.

Brown toured the mainland states, showing films and slides, lecturing, and talking to newspaper editors and politicians. ... Volunteers established new TWS branches. The river's defenders made and distributed films, wrote literature, designed posters, and devised stunts, costumes and floats, including a 30-metre platypus called Franklin aiming to attract attention. ... Supporters held large rallies in Sydney and Melbourne and elsewhere. ${ }^{147}$

All of this activity was directed at convincing the federal government, especially Prime Minister Malcolm Fraser, to intervene and stop the dam. ${ }^{148}$ After a futile and limited effort by Fraser to convince Tasmanian officials to abandon HEC's project, Fraser failed to act, deferring to the authority of Tasmanian state officials. ${ }^{149}$ Efforts in the courts were equally unproductive as a TWS case that sought to block loan money going to the dam's construction failed. ${ }^{150}$

As part of its public education campaign, the TWS also made a substantial economic case against the dam, arguing that hydro development actually resulted in fewer jobs, that continued hydro development was creating unsustainable levels of debt, and that Tasmania would be better off investing in energy conservation and renewable energy. ${ }^{151}$ By making this economic argument, TWS "gave its cause enhanced credibility." 152

While none of the conservationists' arguments, lobbying, petitioning, educating, litigating, and demonstrating carried the day, the ground had been prepared for success.

While Fraser's failure to act decisively against the dam spurred the conservationists to begin plotting a federal electoral strategy, TWS

146. BUCKMAN, supra note 138 , at 47.

147. William J. Lines, The Franklin River Campaign - Part 3 - The Franklin River Campaign Goes National, WILDERNESS SOC'Y, https://web.archive.org/web/20110308063654/ http://www.wilderness.org.au/campaigns/forests/the-franklin-river-campaign-part3 (last updated June 23, 2010) [hereinafter Lines, Part 3].

148. Lines, Part 3, supra note 147.

149. Lines, Part 3, supra note 147.

150. BUCKMAN, supra note 138 , at 48 .

151. BuCKMAN, supra note 138, at 50-51.

152. BUCKMAN, supra note 138 , at 50. 
activists in Tasmania prepared for civil disobedience. ${ }^{153}$ With the public well-prepared by the pre-civil disobedience campaign to understand the merits of the conservationists' cause, Brown announced in November of 1982 that a peaceful, nonviolent blockade of dam construction would start the following month. ${ }^{154}$

Activists, who had likewise been educated by the pre-civil disobedience campaign, poured in from all over Australia. ${ }^{155}$ The first blockade took place on December 14, 1982; 43 were arrested and the action received "saturation media coverage." 156 More blockade actions were conducted through December - with a break for Christmas - and January. ${ }^{157}$ The number of arrests mounted. Those taken into custody included a world-famous botanist, an influential Tasmanian businessman, federal and state politicians, and Bob Brown himself. ${ }^{158}$

The leadership of the federal government had earlier called for a nationwide election in March. By March, arrests numbered in excess of 1,200 blockaders. ${ }^{159}$ By one participant's account, "[t]he blockade and the expected change of government had blown away all the resignation and despair felt by our supporters since the disastrous state election the year before. Nothing could stop us. . .."160

153. See Buckman, supra note 138 , at 50-52.

154. See BucKman, supra note 138 , at 52-53. The blockade would consist principally of people in rubber boats on the Franklin trying to block the path of construction equipment being moved down the river. Pictures of the blockade, as well as a timeline of the blockade, can be found in THE BlockADERS, THE FrankLin BlockAdE (1983). One iconic photo, "broadcast ... across Australia," shows a line of rubber boats stretched across the river with paddles raised in defiance. Id. at 24. See also id. at 86 .

155. "A total of 2,613 people registered" with a blockade information center in Tasmania. THE FRANKLIN BLOCKADE, supra note 154, at 9.

156. William J. Lines, The Franklin River Campaign - Part 4 - World Heritage Protection Bill Passed, WILDERNESS SOC'Y, http://www.wilderness.org.au/campaigns/forests/frankin-rivercampaign-part4 [https://perma.cc/RU3L-2PRR] (last updated June 23, 2010) [hereinafter Lines, Part 4]. Geoff Law reports that arrests and imprisonment of the blockaders was given "prominent coverage ... and the news was greeted with incredulity. It seemed like such a heavy-handed tactic

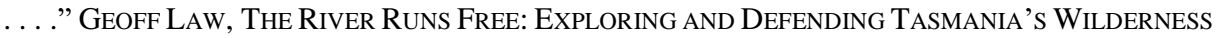
165 (2008). Greg Buckman notes that the blockade "created imagery that television and newspapers could not get enough of ...." BUCKMAN, supra note 138, at 52.

157. Lines, Part 4, supra note 156.

158. Lines, Part 4, supra note 156.

159. The final number of people arrested came to 1,271. Forty-four were arrested twice and four were arrested four times. The most common charge by far was trespass. THE FrANKLIN BLOCKADE, supra note 154, at 9.

160. LAw, supra note 156, at 189. It was Bob Brown's view that, with the election looming, "the blockade was still an essential part of the campaign." LAw, supra note 156, at 195. The blockade continued through the eve of the election. About its conclusion, Geoff Law reflected:

The blockade was over at last. It had achieved its objective. We had peacefully defied the HEC and the state government. Thousands of people had participated. More than fourteen hundred had been arrested, and many of those had gone to 
The TWS and other conservationists campaigned vigorously, asking voters "'to put Australia's heritage above party politics' and urged a vote in favour of the Franklin by endorsing the Labor Party in the House of Representatives and the Australian Democrats in the Senate." 161 The antidam forces won. Bob Hawke, Prime Minister-elect and leader of the victorious Labor Party, had campaigned against the dam and had pledged to "use all the powers at our disposal to ensure that the dam is not proceeded with." 162 In his election-night victory speech, he proclaimed, "[t]he dam will not go ahead."163

When the federal government moved to block construction of the dam, the lawfulness of its action was challenged in the courts by the prodam forces. ${ }^{164}$ The challenge was denied in a High Court decision that is a landmark of Australian constitutional and environmental law. ${ }^{165}$

The dam would not be built. ${ }^{166}$

Anti-dam civil disobedience came after the other more traditional aspects of the campaign to save the Franklin had prepared the way and, by continuing up to the federal election, it helped make the dam a pivotal issue for enough of Australia's voters to swing the election to Hawke and his party. In sum, the disobedience created leverage. Here is how Bob Brown put it:

The Franklin Blockade did not stop one bulldozer. But it did stop the dam. It allowed the beauty of the river to speak through TV screens in millions of living rooms to every Australian. And it elevated the environment to national thinking. 167

The effort to save the Franklin is a textbook illustration of a wellstructured campaign. It used virtually every lawful means to convince decision-makers not to build the dam before turning to civil disobedience. When it did turn to civil disobedience, the movement was able to

jail. The Franklin River had made news all over the country and often internationally.

LAW, supra note 156 , at 224.

161. Lines, Part 4, supra note 156.

162. Bob Hawke, Leader, Austl. Labor Party, Election Speech delivered at Sydney, New South Wales (Feb. 6, 1983) (transcript available at https://electionspeeches.moadoph.gov. au/speeches/1983-bob-hawke [https://perma.cc/G6RH-4BLS]).

163. GRIFFITHS, supra note 134, at 221.

164. GRIFFITHS, supra note 134, at 221.

165. See B. Galligan, The Dams Case: A Political Analysis, in The South West Dam Dispute: The Legal and Political Issues 102, 102-21 (M. Sornarajah ed., 1983).

166. BUCKMAN, supra note 138 , at 54 .

167. BuCKMAn, supra note 138, at 54 (citing Mike Steketee, Just Call Me Responsible, THE Australian, Nov. 8, 2007, at 15). 
capitalize on the groundwork that had preceded it. The media, the public, and the electorate were prepared to be persuaded.

\section{E. Timeliness of Action}

Civil disobedience can be effective in creating change when, similar to the disobedience to save the Franklin, it occurs at a time when the national conversation includes substantial discussion and consideration of the discrete relief that the disobedients seek. Thanks to the earlier noncivil disobedience phases of the Franklin River campaign, saving the Franklin was part of the national conversation in Australia when the Franklin River blockade took place. The civil disobedience of the blockade sharpened the issue in the public's mind, injected the fate of the Franklin into the federal election, and leveraged public opinion to put pressure on decision-makers. None of this would have been possible at an early stage in the campaign; neither the public nor politicians would have assigned the issue as much weight as they did at the time the blockade took place.

Consider the civil disobedience that occurred in the late nineteenth and early twentieth centuries in support of women's suffrage. When Susan B. Anthony committed her act of civil disobedience in 1872, the notion of a constitutional amendment was not in the national conversation. ${ }^{168}$ Had Anthony been aiming for a new constitutional amendment in 1872 , it would have been highly unlikely that she and her colleagues would have seen one enacted.

The Nineteenth Amendment was not introduced in Congress until 1878, six years after Anthony's attempt to vote in Rochester. A major roadblock was what one scholar calls "insuperable barriers."169 Suffragists turned to a state-by-state strategy with the thought that pressure could be made to bear on Congress to pass a federal amendment when the states passed their own suffrage laws. ${ }^{170}$ Indeed, between 1910

168. Rather, the discussion at that time centered on the argument that the federal constitution already provided for the vote for women, an argument made in the popular media as well as before the courts in voting rights cases by Susan B. Anthony and other suffragists. Ellen CAROL DuBois, Women SuFFRAGE AND Women's Rights 101 (1998). The courts rejected the argument.

169. Kris W. Kobach, Rethinking Article V: Term Limits and the Seventeenth and Nineteenth Amendments, 103 YaLE L. J. 1971, 1980 (1994). "[A]n inherent structural interest in Congress made the proposal of a constitutional amendment virtually impossible under the existing institutional framework - sitting Congressmen were unwilling to risk their seats by trying their luck with an electorate that included women." Id. The amendment was actually voted on in the Senate in 1887; it was handily defeated, 16 to 34, "a far cry from the two-thirds positive vote required for passage.” AleXANDER Keyssar, The Right to Vote: The Contested History of DEMOCRACY IN THE UNITED STATES 185 (2000). It would not be voted upon again in the Senate until 1914 and not voted upon at all during this period by the House. Kobach, supra note 169, at 1981.

170. "Faced with unyielding congressional inaction, suffragists turned to the states ...." 
and 1918, women's suffrage had won at the polls in eleven states. ${ }^{171}$ When the Silent Sentinels began to picket the White House in 1917, "[s]uffragists anticipated that their moment had come."172 The work the suffragists did between 1878 and the early twentieth century had placed the notion of amending the constitution to give women the right to vote squarely within the national conversation. Professor Alexander Keyssar writes:

[S]uffrage organizations planted themselves in towns, cities, wards, and precincts throughout the country; they imaginatively generated attention-getting demonstrations of strength; and they pressured political leaders in Washington and the states. In New York, the Women Suffrage Party adopted Tammany Hall's techniques of precinct-level organizing; in California, the Equal Suffrage Association canvassed door to door and distributed millions of pamphlets. ${ }^{173}$

Because of the hard work of those who went before them, women's suffrage was a real, live possibility for those suffragists arrested, convicted, and jailed in 1917. ${ }^{174}$

For civil disobedience to be effective in creating change, the soughtafter relief must have a place in the national conversation. Civil disobedience that is mounted before the target issue is taken seriously in the national conversation may do well in advancing the debate, but it is

Kobach, supra note 169, at 1981. An "aging Susan B. Anthony" said, "I don't know the exact number of States we shall have to have, . . . but I do know that there will come a day when that number will automatically and resistlessly act on the Congress of the United States to compel the submission of a federal suffrage amendment. And we shall recognize that day when it comes." Quoted in Kobach, supra note 169, at 1981 (citing CARRIE C. CATT \& NETTIE R. SHULER, WomAN SuFFrAGE AND Politics 227 (1926)). The state-by-state approach was then followed by Carrie Catt's "Winning Plan" that relied on lobbying Congress. Robert Booth Fowler \& Spencer Jones, Carrie Chapman Catt and the Last Years of the Struggle for Woman Suffrage: "The Winning Plan", in Votes For Women: The Struggle For SufFrage Revisited 130, 135 (Jean H. Baker ed., 2002).

171. Kobach, supra note 169 , at 1982. The effort to earn suffrage victories at the state level was not immediately or widely successful. See KEYSSAR, supra note 169, at 186.

172. Kobach, supra note 169, at 1982.

173. KEYSSAR, supra note 169 , at 203.

174. "The woman suffrage bill first became a live issue in Congress because of the activity of the Congressional Union; of this there can be no doubt. In weighing its role (and that of its successor, the Woman's Party) and evaluating its contribution to the winning of women suffrage, attention has too often been concentrated on the phase of the Union's activity which began in 1917, when Alice Paul's organization went over to the 'militant' tactics adapted from British suffragists, such as picketing the White House, bonfires, hunger strikes in protest against getting arrested, etc. But to do so is to overlook the long stretch of work, beginning in 1913...." FLEXNER, supra note 42, at 279. For a perceptive in-depth accounting of the forces that produced the nineteenth amendment, see KEYSSAR, supra note 169, at 172-76. 
not likely to create the movement's intended change. This point is obviously related to the principle of campaign integration. A large part of putting an issue into the national conversation is pre-civil disobedience education of the public and politicians about the wrong the movement intends to right. Disobedients who move straight to disobedience without first doing the long, hard work of campaigning are placing their faith in a short-cut that has a low chance of creating change.

\section{OVERCOMING AN INHERENT DISADVANTAGE}

Climate disobedients start with an immediate and inherent disadvantage. By definition, virtually all climate change disobedience is indirect civil disobedience.

When Susan B. Anthony voted in 1872, she did so in violation of an act of Congress that effectively prohibited women from voting. When Gandhi marched to the sea at Dandi in 1930 to make salt, he broke British laws against private salt-making that were intended to hold the saltmaking monopoly of the British colonial government in place. When black college students in 1960 sat down at a white-only lunch counter in Greensboro, North Carolina and then at other segregated lunch-counters throughout the South, they violated the laws and customs that prohibited blacks from eating with whites.

Why are these three instances of civil disobedience so well-known today? Why were they so effective? In each of these instances, the disobedients performed the very acts that they were prohibited from doing-voting, making salt, presenting themselves for service at lunch counters. They were arrested for breaking the very laws and customs to which they objected. Their disobedience was, in a word, direct-the deliberate violation of the laws to which they objected. In direct civil disobedience there is usually a very close connection-and often an identity-between the act the disobedient performs and the right the disobedient seeks to assert. A close connection between the act and the right permits the public to readily understand the wrong at which the disobedients' act is aimed. As explained elsewhere in this Article, public understanding is at least helpful and sometimes essential to the disobedient's mission of changing the status quo.

Climate change disobedients labor in a field in which there are almost no opportunities for direct civil disobedience. The laws and customs climate activists find objectionable rarely open themselves to disobedience by climate activists. Consider, for example, the Trump administration's proposal to relax fuel economy standards for American cars and trucks. ${ }^{175}$ Because the relaxation of these standards will result in

175. Brady Dennis et al., Trump Administration to Freeze Fuel-efficiency Requirements in Move Likely to Spur Legal Battle with States, WASH. Post (Aug. 2, 2018), 
a significant increase in greenhouse gas emissions as compared to the effect of the regulations they are replacing, climate activists oppose the proposal. ${ }^{176}$ The administration intends to work its will through a change to regulations issued by the Environmental Protection Agency. ${ }^{177}$ These regulations do not apply to the public; they apply to vehicle manufacturers. Climate activists have no opportunity to protest these regulations by breaking them. The regulations do not apply to them.

If climate activists want to deploy civil disobedience against this change in the EPA regulations, they likely would consider occupying EPA offices, blocking roads workers use to enter vehicle-manufacturing plants, interrupting public appearances of the EPA administrator and the executives of vehicle manufacturers, and the like. Climate activists generally have no quarrel with our laws against trespass, blocking roads, and disorderly conduct - but those are the laws they will be violating and under which they will be arrested and prosecuted should they participate in the acts described above. Their disobedience, accordingly, would be indirect. They are not violating laws with which they disagree. They are violating other laws with which they do not disagree to express their opposition to laws with which they do disagree. Indirect civil disobedience is the violation of a law with which the disobedient has no quarrel to protest a wrong unrelated to the law being violated. ${ }^{178}$

Quite clearly, it is more difficult to achieve public understanding of the wrong being protested when the disobedience is indirect because indirect civil disobedience makes it more difficult for disobedients to communicate the nature and extent of their grievances to the public; there is no connection between the act of disobedience and the wrong that is being protested. In direct civil disobedience, the public can easily see, and can often easily relate to, the wrong that is targeted. In indirect civil disobedience, the public has to do more work to uncover the wrong; the public has to peel back the disobedience that is being performed and look underneath for the true object of the disobedients' protest. This is not a function the public performs readily or well, chiefly because media reports tend to focus on the disobedient act, rather than on the underlying grievance.

Accordingly, climate change disobedients may have an interest in

https://www.washingtonpost.com/national/health-science/2018/08/01/90c818ac-9125-11e8-832 2-b5482bf5e0f5_story.html?utm_term=.726a4389fcb7 [https://perma.cc/PUX7-T7HL]; see generally SAFE Vehicles Rule 183 Fed. Reg. 42,986, 43,500 (Aug. 24, 2018) (to be codified at 49 C.F.R. pt. 85, 86).

176. Coral Davenport, Trump Administration Unveils Its Plan to Relax Car Pollution Rules, N.Y. TimES (Aug. 2, 2018), https://www.nytimes.com/2018/08/02/climate/trump-auto-emissions -california.html [https://perma.cc/BA72-NUES].

177. See generally SAFE Vehicles Rule 183 Fed. Reg. 42,986, 43,500 (Aug. 24, 2018) (to be codified at 49 C.F.R. pt. 85, 86).

178. Brownlee, supra note 6 . 
lessening the difficulties their indirect disobedience causes them. They can do this in three ways. ${ }^{179}$ First, they can choose actions that do not burden the public. When indirect civil disobedience projects inconvenience on to the public, the public becomes less interested in putting in the extra effort to learn the nature and extent of the disobedients' grievance. Blockades of offices and highways make the point. They interfere with the lives of members of the public who have no direct connection to the issue, turning those whom the disobedients intend to influence, into angry opponents. Members of the public who are not directly inconvenienced, but who learn of the blockade through the media are more likely to associate themselves with the inconvenienced public than with the disobedients. Each sub-set of the public has been provided an incentive not to make the effort to inquire into the disobedients' actual grievance.

The second thing climate activists can do is found on the other side of the same coin: they can deliberately design their disobedience to encourage curiosity. What encourages curiosity? Creativity. Disobedience that is creative is disobedience that encourages the public to give the relevant issue a fresh look. ${ }^{180}$

Third and lastly, climate activists can create as close a connection as possible between their disobedience and the wrong being attacked. This can sometimes be done by moving the disobedience to the location of the wrong. In a protest of mountaintop removal mining, there is no apparent connection between trespassing in the offices of a governor and the wrong being attacked. ${ }^{181}$ A protest held on a mountaintop removal mining site or a protest involving the machinery used in mountaintop removal mining makes a still imperfect but stronger connection between the wrong and the act of trespass. The public can somewhat more easily shift its focus from the act of trespass to the problems with mountaintop removal mining. ${ }^{182}$

179. This is especially true when the goal of the disobedients is to garner public sympathy. If the goal, by contrast, is to draw publicity, then this consideration may play out somewhat differently. See the discussion in Part II of this paper about the purposes of civil disobedience.

180. While creative disobedience tactics can be used to further many disobedience purposes, such tactics are most useful for disobedients whose purpose is publicity. See supra Part II (discussing principles for effective climate change disobedience).

181. See, e.g., the protest that occurred in February 2011, when a group of protestors, including poet Wendell Berry, occupied the offices of Kentucky governor Steve Beshear. The group was protesting mountaintop removal mining. See Ken Ward Jr., Kentucky Protest Ends with Rally, COAL TATTOO (Feb. 15, 2011), http://blogs.wvgazettemail.com/coaltattoo/2011/ 02/15/kentucky-protest-ends-with-rally/ [https://perma.cc/497H-ZP2F].

182. Moving the protest to the location of the wrong leads to an accompanying increase in the difficulty of drawing media attention to the protest. It's much easier for the media to appear at an office building in town than to travel to a remote spot in the countryside. This fact of media life puts pressure on the disobedients to find admittedly imperfect work-arounds - such as increased use of social media and supplying the press with photos and news releases. 
Julia Butterfly Hill was strikingly successful in overcoming the difficulties associated with indirect civil disobedience when she conducted her 738-day tree sit in Humboldt County, California, from December 1997 to December 1999 to protest the threatened clear-cutting of a stand of old-growth redwood trees, including the one in which she was sitting. ${ }^{183}$ While other tree-sits previously had taken place in the United States and elsewhere, no one had ever undertaken a sit of this duration. ${ }^{184}$ Hill's novel disobedience drew widespread public attention and curiosity through significant media coverage, was memorialized in film and song, and resulted in a settlement with the logging industry that saved her tree and a swath of neighboring redwood trees. ${ }^{185}$

Hill's disobedience was indirect because she had no quarrel with the laws of trespass that she was violating. Rather, she was trespassing because it was a way to get at the wrong she opposed-clear-cutting redwoods. Hill was able to overcome the inherent disadvantages of indirect civil disobedience and to make her disobedience effective because her disobedience (1) did not burden the public, (2) was sufficiently novel to encourage curiosity, and (3) drew a fairly close connection between the disobedience and the wrong of which she complained.

\section{EXTINCTION REBELLION: A PRELIMINARY ANALYSIS}

As this Article is being written, the most extensive climate disobedience campaign ever mounted, Extinction Rebellion (or "XR," as it is known), is unfolding in the United Kingdom. ${ }^{186}$ It offers an opportunity to analyze the effectiveness of climate change disobedience through the lens of the principles discussed above.

\section{A. Disruption}

Over a thousand climate activists have been arrested. ${ }^{187}$ The arrestees, along with thousands more "rebels," as they call themselves, have

183. Julia Butterfly Hill, The Legacy of Luna (2000).

184. See Julia Butterfly Hill Defends California Redwoods, 1999, supra note 41 (discussing how at the time of Hill's tree-sit, the previous record for tree sitting was 90 days).

185. See Julia Butterfly Hill Defends California Redwoods, 1999, supra note 41. Neither this example nor some of the additional examples cited hereafter are necessarily intended to represent climate change civil disobedience. There are very few useful examples of climate change disobedience. Accordingly, I draw from closely-related examples of environmental disobedience. Climate change activists have not yet had sufficient experience with civil disobedience to build up a bank of helpful illustrations.

186. Nosheen Iqbal, How Extinction Rebellion Put the World on Red Alert, THE GuARDIAN (Oct. 6, 2019, 4:13 AM), https://www.theguardian.com/environment/2019/oct/06/how-extinction -rebellion-put-world-on-red-alert-year-since-it-was-founded [https://perma.cc/F474-R3YG].

187. First Extinction Rebellion Protesters Appear in Court, BBC News (July 12, 2019), https://www.bbc.com/news/uk-48968947 [https://perma.cc/2YU5-3T3J]. 
disrupted the normal operation of streets, bridges, squares, meetings, offices, public transport, and more in London and elsewhere. Among their acts of civil disobedience, activists have blocked traffic, poured blood in public places, engaged in a protest disrobing, spray-painted words of protest on government and corporate office buildings, and glued themselves to various objects, including doors, fences, tram cars, and each other. ${ }^{188}$

XR disobedience has unfolded in three main phases. The first phase occurred in November and December 2018. Activists blocked traffic on Downing Street, glued themselves to fencing, blocked access to the Southwark, Blackfriars, Waterloo, Westminster, and Lambeth bridges in London, formed "swarming roadblocks" to unpredictably prevent access to important streets in central London, and blocked access to BBC offices. $^{189}$

In April of 2019, rebels occupied several significant public spaces in London around the clock-Marble Arch, Oxford Circus, Waterloo Bridge, and Parliament Square. ${ }^{190}$ They also glued themselves to the doors of Shell's offices and painted "Shell Knew," "Shell Knows," and "Climate Criminals" on the Shell building. ${ }^{191}$ They obstructed the overground tube at Canary Wharf station and glued and chained

188. Phoebe Cooke, Peel Off for the Planet, THE Sun (Oct. 12, 2019), https://www.thesun.co.uk/news/10122216/extinction-rebellion-climate-change-protesters-nude/; Extinction Rebellion Protestors to Spray Paint Westminster During 'Red Handed' March, INDEPENDENT (Oct. 18, 2019, 12:52 AM), https://www.independent.co.uk/news/uk/homenews/extinction-rebellion-protests-london-today-spray-paint-red-handed-march-a9160876.html; Iqbal, supra note 186; Sarah Marsh, Extinction Rebellion Activists Glue Themselves to DfT and Home Office, THE GUARDIAN (Oct. 8, 2019, 8:33 AM), https://www.the guardian.com/environment/2019/oct/08/extinction-rebellion-activists-glue-themselves-to-homeoffice-and-dft [https://perma.cc/2WNR-C7KY].

189. Matthew Taylor \& Damien Gayle, Dozens Arrested After Climate Change Protest Blocks Five London Bridges, The GuARDiAN (Nov. 17, 2018, 10:31 AM), https://www.the guardian.com/environment/2018/nov/17/thousands-gather-to-block-london-bridges-in-climaterebellion [https://perma.cc/ABC4-5HZE]; Jonathan Watts, Extinction Rebellion Goes Global in Run-up to Week of International Civil Disobedience, THE GuARDIAN, (Dec. 10, 2018, 5:29 AM), https://www.theguardian.com/world/2018/dec/10/extinction-rebellion-goes-global-internationalcivil-disobedience-climate-talks-poland, Neither this description, nor the description below highlighting XR's Spring, 2019 activities, is intended to be a complete account of XR's extensive activities during the periods discussed.

190. See First Extinction Rebellion Protesters Appear in Court, supra note 187.

191. Jamie Bullen, Extinction Rebellion: Shell HQ Windows Smashed as Climate Protest Blocks London Roads 1, THE TELEGRAPH (Apr. 16, 2019, 1:06 AM), https://www. telegraph.co.uk/news/2019/04/15/extinction-rebellion-activists-threaten-bring-london-standstill/ [https://perma.cc/69NC-MZSG]; Kelly Gilblom, Shell's London Headquarters Vandalized by Climate Protesters, BloomberG (Apr. 15, 2019, 8:23 AM), https://www.bloomberg.com/ news/articles/2019-04-15/shell-s-london-headquarters-vandalized-by-climate-protesters [https:// perma.cc/9L5K-UGYT]. 
themselves to the fence outside Labour leader Jeremy Corbyn's house. ${ }^{192}$ Meanwhile, similar actions took place at numerous international locations as well.

The most recent phase - the "summer rebellion"-began on July 15, 2019 with rebels intending to cause disruptions to the operation of public roads and spaces in London and five other UK cities-Bristol, Cardiff, Glasgow, and Leeds. ${ }^{193}$

It is quite likely that by the time this Article goes to press, additional sets of actions and reactions will merit analysis.

\section{B. XR Successes}

One of the two principal purposes of climate change disobedience is to advance the debate by making the disobedients' concern with climate change part of the national conversation. In this regard, XR has been strikingly successful. All manner of media outlets in the United Kingdom, from The Telegraph to the BBC to The Guardian, provided extensive coverage to XR; moreover, and not coincidentally, politicians wanted to be seen by the public talking about climate change. In a significant sign of success in this area, several prominent governmental and political figures invited XR representatives to meet with them-London Mayor Sadiq Khan, Secretary of State for Environment, Food and Rural Affairs Michael Gove, and John McDonnell, Shadow Chancellor of the Exchequer, representing the Labour Party. ${ }^{194}$ The House of Commons gave an hour-and-a-half to a discussion of the "Extinction Rebellion Urgent Question." 195 The discussion included a "call from Ed Miliband for a government declaration of climate emergency and the implementation of a 'green new deal.",196

XR put climate change in the front and center of the national conversation. What made this effort so successful? First, XR did its

192. See First Extinction Rebellion Protesters Appear in Court, supra note 187.

193. From Monday 15 July Extinction Rebellion's 'Summer Uprising - ACT NOW!' to Cause Major Disruption Across Five UK Cities, Extinction Rebellion (July 10, 2019), https://rebellion.earth/2019/07/10/from-monday-15-july-extinction-rebellions-summer-uprisingact-now-to-cause-major-disruption-across-five-uk-cities/ [https://perma.cc/6J2E-42SW].

194. Jonny Bairstow, Shadow Chancellor John McDonnell Meets Extinction Rebellion, ENERGY Live NEws (Apr. 30, 2019), https://www.energylivenews.com/2019/04/30/shadowchancellor-john-mcdonnell-meets-extinction-rebellion/ [https://perma.cc/HF8B-DESY]; Extinction Rebellion: Activists Say Meeting with Michael Gove 'Disappointing', BBC NEws (Apr. 30, 2019), https://www.bbc.com/news/uk-politics-48109764 [https://perma.cc/P32M-FX5Y]; Adam Forrest, Sadiq Khan Meets Extinction Rebellion Protesters and Promises to Consider Citizens' Assembly on Climate Change, InDEPENDENT (Apr. 29, 2019, 10:47 PM), https://www.independent.co.uk/climate-change/news/extinction-rebellion-sadiq-khan-climatechange-protests-meeting-london-michael-gove-a8892106.html

195. Rebel Writers, Update \#7 - To Parliament, and Beyond, ExTINCTION Rebellion (Apr. 25, 2019), https://rebellion.earth/2019/04/25/update-7-to-parliament-and-beyond/.

196. Id. Miliband is a former Leader of the Labour Party. 
homework. It studied nonviolent change ${ }^{197}$ as practiced by Gandhi and King and as taught by Gene Sharp, Erica Chenoweth, and Maria Stephan. With the awareness that nonviolent change does not simply happen on its own accord, XR followed up with extensive pre-event planning. ${ }^{198}$

Second, XR engaged in creative tactics. I will highlight two here. The first is gluing. ${ }^{199}$ When activists glued themselves to the objects mentioned earlier, they got the attention of the media. A picture of activists glued to each other, Robocop style, blocking an entrance to the London Stock Exchange, ${ }^{200}$ was irresistible for most media outlets. Media outlets were similarly attracted to pictures of rebels glued to trains, some with nearby notes reading "Super glued. Do not pull me" and the like. ${ }^{201}$

XR's creativity extended to the nature of its campaign. It decided well in advance to attract people to its movement by making a rebel's presence at its various actions fun. Fun is not a concept often associated with protest. $^{202}$ Drawing on the teaching of Chenoweth and Stephan to make participation in the movement as accessible to ordinary people as possible so as to increase numbers and consequently increase pressure on government, ${ }^{203} \mathrm{XR}$ brought in eye-catching floats, ${ }^{204}$ hosted the

197. XR has a statement of ten principles and values. Ninth among them is: "We are a nonviolent network." About Us, EXTINCTION REBELLION, https://rebellion.earth/the-truth/about-us/ (last visited Apr. 23, 2020).

198. For the importance of planning, see SRDJA Popovic, BLuEPRINT FOR REVOLUTION: How Use Rice Pudding, Lego Men, and Other Nonviolent Techniques to Galvanize COMmunities, Overthrow Dictators, OR Simply CHANGE THE WORLD 180 (2015).

199. Extinction Rebellion: UK Protesters Are Supergluing Themselves to Buildings to Fight Climate Crisis, DEMOCRACY Now (Dec. 14, 2018), https://www.democracynow.org/2018/12/14/extinction_rebellion_uk_protesters_are_supergluin g.

200. Id.

201. Richard Hartley-Parkinson, Climate Change Protesters Bring DLR to Halt by Targeting Train at Canary Wharf, METRO UK (Apr. 17, 2019, 10:59 AM), https://metro.co.uk/2019/04/17/extinction-rebellion-protesters-glue-dlr-train-canary-wharf9231433/

202. Srdja Popovic, a leader of the Otpor nonviolent rebellion, preaches the importance of fun. See POPOVIC, supra note 198, at 123.

203. Stephan \& Chenoweth, supra note 20, at 96.

204. Emma Snaith \& Ali Mitib, Extinction Rebellion Bring London Streets to Standstill Amid Fresh Wave of Coordinated Protests Across UK, InDEPENDENT (July 15, 2019, 4:26 PM), https://www.independent.co.uk/news/uk/home-news/extinction-rebellion-protests-londonbristol-cardiff-leeds-glasgow-climate-change-a9005531.html ("Five colourful boats have been used to stop traffic in Cardiff, Glasgow, Bristol, Leeds and the capital as part of the group's weeklong 'summer uprising.'”). 
performance of bands, ${ }^{205}$ and put on activities for families, ${ }^{206}$ all of which created a party atmosphere. The message communicated to the public was that the protest activities taking place were safe and being conducted by ordinary folk. It was a marketing success. Not only did XR attract thousands to the physical sites of its disobedience, it also succeeded in signing up 40,000 new members by late April $2019^{207}$ and in raising nearly $£ 300,000$ in crowdfunding. ${ }^{208}$

\section{Did Extinction Rebellion Create Substantive Change?}

The second possible major purpose of climate change disobedience is to create social and political change. At the start of its campaign, XR announced its change goals:

- The Government must admit the truth about the ecological emergency

- The Government must reverse all policies inconsistent with addressing climate breakdown, and work alongside the media to communicate with citizens

- The Government must enact legally binding policy measures to reduce carbon emissions to net zero by

205. See Tom Batchelor, Extinction Rebellion: Hundreds of Arrests as Protesters Target London Transport Network and Jeremy Corbyn's Home, INDEPENDENT (Apr. 17, 2019, 5:59 PM), https://www.independent.co.uk/news/uk/home-news/extinction-rebellion-protests-climatechange-london-tube-jeremy-corbyn-dlr-a8875061.html.

206. XR Families in the Park, ExTINCTION REBELLION, https://rebellion.earth/event/xrfamilies-in-the-park/ [https://perma.cc/XZ8C-SHGT] (last visited Apr. 23, 2020).

207. Rebel Writers, supra note 195.

208. Update \#6 - A New Phase Begins, Extinction Rebellion (Apr. 22, 2019), https://rebellion.earth/2019/04/22/update-6-a-new-phase-begins/. XR should also be given credit for overcoming the disadvantages associated with inconveniencing the public by its road blocks and related actions. Normally disobedients want to take on suffering so that the public sympathizes with them. The projection of suffering on to others often results in anger against the disobedients on the part of those whose support the disobedients are cultivating. XR was sensitive to this and dealt with it by apologizing to the public and by sometimes keeping its road disruptions to very short periods of time. See, e.g., Amy Walker, Extinction Rebellion Boats Banned from London Protests, THE GuARDIAN (July 19, 2019, 7:06 AM), https://www.theguardian.com/ environment/2019/jul/19/extinction-rebellion-protesters-block-site-of-london-super-sewerbermondsey [https://perma.cc/YGT7-VK7J].

When there was talk within XR's ranks of disrupting traffic at Heathrow, however, the public reaction was quite unfavorable. The idea was quickly side-tracked. Extinction Rebellion Grounds Summer Protest Plans for Heathrow, ExTINCTION REBELlion (June 16, 2019), https://rebellion. earth/2019/06/16/extinction-rebellion-grounds-summer-protest-plans-for-heathrow/; Ben Webster \& Fahira Karim, Extinction Rebellion Threaten to Shut Heathrow Down for Ten Days, THE TIMES (June 1, 2019, 12:01 AM), https://www.thetimes.co.uk/article/activists-threaten-to-shut-heathrow -down-for-ten-days-czbxh55rj [https://perma.cc/PH2L-76MG]. 
2025 and to reduce consumption levels

- A national Citizen's Assembly to oversee the changes, as part of creating a democracy fit for purpose. ${ }^{209}$

The wording of these goals went through several iterations during the campaign. The most recent iteration and the iteration XR now seems to be holding to lays out three goals:

- Government must tell the truth by declaring a climate and ecological emergency, working with other institutions to communicate the urgency for change.

- Government must act now to halt biodiversity loss and reduce greenhouse gas emissions to net zero by 2025.

- Government must create and be led by the decisions of a Citizens' Assembly on climate and ecological justice. $^{210}$

Let us examine the effectiveness of XR in achieving social and political change. This essay argued earlier that disobedience has an improved chance of creating such change when certain principles were followed: specificity of goal, evocativeness and media engagement, campaign integration, and timeliness of action.

XR started off on the wrong foot by failing to announce - and stick with - a carefully defined set of goals. Instead, the articulation of XR's goals changed over time. Focus was lacking as to what exactly it was that XR wanted.

Even after one articulation of the goals was finally settled on, specificity was lacking. None of the three parts of XR's first goal is specific. Telling the truth and working with other institutions are not clear, well-defined actions. It is not possible to clearly measure performance or non-performance, compliance or non-compliance. 'Declaring a climate emergency' has the appearance of specificity-but is not actually specific in terms of substantive social and political change. Parliament and several other bodies did, in fact, declare climate emergencies. ${ }^{211}$ This was not, however, a substantive win. As XR itself

209. Over 1000 People Block Parliament Sq to Launch Mass Civil Disobedience Campaign Demanding Action on Climate Emergency, Extinction Rebellion (Oct. 31, 2018), https://rebellion.earth/2018/10/31/over-1000-people-block-parliament-sq-to-launch-mass-civildisobedience-campaign-demanding-action-on-climate-emergency/ [https://perma.cc/JE4T-GAUL].

210. Our Demands, EXTINCTION REBELLION https://rebellion.earth/the-truth/demands/ [https://perma.cc/T3B5-2WHM] (last visited Apr. 23, 2020).

211. Newsletter 20 - Parliament Meets Our First Demand...Well Almost, ExTinction REBELLION (May 3, 2019), https://rebellion.earth/2019/05/03/newsletter-20-parliament-meets- 
warned its constituency, "be under no illusions - this is a symbolic victory. The Government has conceded no extra funds and no new policies. Indeed, it is clear that the Secretary of State still cannot and will not address the dark clouds of apocalypse looming on the horizon." 212 With respect to this first goal, XR may have advanced the debate, but it did not create substantive change. ${ }^{213}$

XR's second stated goal - to have the British government "act now to halt biodiversity loss and reduce greenhouse gas emissions to net zero by 2025 " - was, in rather short order, effectively reduced to the second half of the stated goal, to reduce greenhouse gas emissions to net zero by 2025. ${ }^{214}$ Halting biodiversity loss became, at best, a secondary issue. Not only has XR failed to persuade the government to adopt its 2025 goal, it has not, to date, been able to get the government even to take the 2025 goal seriously. The 2025 goal does not now have a secure place in the UK's national conversation. It is simply not considered part of the discussion. ${ }^{215}$ This is so, in part, because of XR's failure to first mount a

our-first-demand/ [https://perma.cc/7K7X-R72Z].

212. Id.

213. See Martyn McLaughlin, Climate Change: Where Extinction Rebellion Is Going Wrong, The SCOTSMAN (Apr. 17, 2019, 11:42 AM), https://www.scotsman.com/news/opinion/ climate-change-where-extinction-rebellion-is-going-wrong-martyn-mclaughlin-1-4908627 [https://perma.cc/5DPH-CAQ9]. ("For all the urgency of its language, [XR's] goals seem to be lacking in focus. It has no discernible political strategy, and no defined roadmap to move towards its aims. Compare that if you will with the Sunrise Movement, a youth-led political action group in the US, which together with congresswoman Alexandria Ocasio-Cortez, has captured the public imagination with its plan for a Green New Deal.").

214. Our Demands, supra note 210.

215. See, e.g., BBC Newsnight, Extinction Rebellion: Will Climate Change Protests Force a Response?, YouTuBE (Apr. 17, 2019), https://www.youtube.com/watch?v=BTv-KxZXcL4 [https://perma.cc/FLE3-NM35] (arguing that UK must set "more ambitious targets" to get significant change); Extinction Rebellion, Chris Packham On Why We Need a Rebellion, FАСЕВООК (Apr. 21, 2019), https://www.facebook.com/ExtinctionRebellion/posts/chrispackham-on-why-we-need-rebellion-just-a-couple-of-days-before-comingdown/364770670805714/ [https://perma.cc/M387-XRY6](noting XR promotes Packham's views). An interview conducted by BBC's Elizabeth Glinka with the well-known naturalist Chris Packhan is telling:

"One of their stated aims is zero carbon emissions into the next 5 or 6 years. But that would mean massive changes for individuals. Wouldn't it? Basically, no flights, no cars, a huge increase in renewable energy. Is that really possible? Can that really happen?"

Chris Packham, interviewee:

"Well, I think what you do, you aim for the stars to get to the sky, don't you? And you aim for the sky to climb to the top of the tree. I think we have to set far more ambitious targets to spur people into thinking about this."

BBC Newsnight, supra note 215, at 3:01-3:30. 
sufficiently lengthy and forceful non-civil disobedience education campaign on the issue. Such a campaign would have laid the groundwork necessary to force the government to take 2025 seriously. Without such a campaign the government was free to acknowledge that there was a climate crisis - and then slough it off with the assurance that carbon reductions by 2050 would address the problem. A campaign could have made 2025 a serious issue; it would then have been up to XR to introduce its disobedience at a time when it could have leveraged public opinion, namely when there was at least a toehold of political support to justify forcing the 2025 issue with disobedience.

Had that moment existed, would XR's disobedience have been sufficiently evocative to attract public sympathy? Probably not, given the difficulties described earlier with indirect civil disobedience. XR did a masterful job, however, in overcoming this drawback by instead relying on large-scale participation in its civil disobedience actions. Linked to a goal that had already been taken seriously in the public discussion, this mass withdrawal of consent might have been sufficient to carry the day.

Much the same analytic framework can be used to assess XR's lack of success in reaching its third goal-having the government create and be led by the decisions of a Citizens' Assembly. ${ }^{216}$ When XR began its disobedience, the public case had not been made for such an assembly. Because it was not in the national conversation and because there was no extant political support for it, disobedience over the assembly issue had no traction. Disobedience could be not used as a lever to push the issue over the finish line. Not surprisingly, the government never took this demand seriously. ${ }^{217}$

216. Our Demands, supra note 210.

217. The Parliament announced plans to conduct a "Citizens Assembly", but it will bear no substantive resemblance to what XR sought. Select Committees Announce Plans for Citizens' Assembly, PARLIAMENT (June 20, 2019), https://committees.parliament.uk/committee/365/ business-energy-and-industrial-strategy-committee/news/96965/select-committees-announceplans-for-citizens-assembly/\#: :text=Six $\% 20$ select $\% 20$ committees $\% 20$ of $\% 20$ the, achieving\% 20the\%20pathway\%20to\%20net.

XR recognized this immediately: “...[W]e cannot pretend that this is a legitimate assembly with real or legislative power. If the judicial system can depend on juries, why can people not be trusted with policy? It is encouraging news but-let us be clear-politicians have not met our third demand today. There is a very long way to go. A half arsed attempt at a Citizens' Assembly will doom the process and the results. Please do not make this mistake." Ronan, Response to Select Committees Announcing a Citizens' Assembly - Have We Achieved Our Third Demand?, EXTINCTION REBELLION (June 20, 2019), https://rebellion.earth/2019/06/20/response-to-selectcommittees-announcing-a-citizens-assembly-have-we-achieved-our-third-demand/ [https://perma. cc/T2GT-TB6M]. 


\section{CONCLUSION}

Extinction Rebellion's civil disobedience has clearly advanced the climate change debate in the UK into a higher key. Over one thousand rebels have paid for this development by making themselves vulnerable to arrest and prosecution. ${ }^{218}$

$\mathrm{XR}$, the first large-scale, mass, climate disobedience movement, has proven itself to be both innovative and thoughtful. We now wait to see whether the movement can adjust its future course, by transforming its further sacrifice of freedom into the social and political change all those concerned with the existential threat posed by climate change so desperately want. 